\title{
AVALIAÇÃO DO TEOR DE SOLO EM CARREGAMENTOS DE CANA-DE-AÇÚCAR POR RADIOATIVIDADE INDUZIDA
}

\author{
elisabete A. DE NADAl fernandes \\ Engenheiro Agrônomo
}

Orientador: Prof. Dr.

ipaMINONDAE S. B. FERRAZ

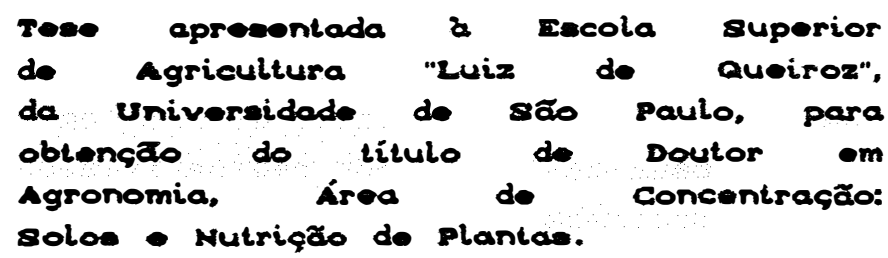

PI RACI CABA

Eatado do são Paulo - akasIL

Outubro - 1908 
Fernandes, Elisabete A. De Nadai

iF363a Avaliação do teor de solo em carregamentos de cana-de-açúcar por radioatividade induzida. Pí racicaba, 1988.

$103 \mathrm{p}$.

Tese - ESALQ

Bibliografia.

1. Análise por ativação neutrônica 2. Cana-deaçúca: - Carregamento - Impureza 3. Cana-de-açúcar - Teor de solo - Análise nuclear I. Escola Superior de Agricultura Luiz de Queiroz, Piracicaba

CDD 633.61 


AVALIAÇÃO DO TEOR DE SOLO EM CARREGAIMENTOS DE
CANA-DE-ACUUCAR POR RADIOATIVIDADE INDUZIDA

elisabete A. DE nadal fERnandes

Aprovada em: 13.12.88

Comissão julgadoras

Prof. Dr. Epami nondas S.B. Ferraz

ESALQ USP

Prof. Dr. Jose Paulo Stupi ello ESALQ USP

Pror. Dr. Virgilio F. do Nascimento Fo ESALQ USP

Prof. Dr. Rarael Roberto Al oisi ESALQ/USP

Prof. Dr. Otaviano A. M. Helene IF USP

Prof - EPAMINONDAS S. B. FERRAZ ORIENTADOR 
Cada um contribuiu com parte de seu conhecimento, esforco pessoal e amizade na realizacăo deste trabalho. Como mérito final, dedico-o integralmente a todos, com o mesmo respeito e dignidade. Seus nomes, com certeza, guardá-los-ei em minha lembrança.

Agradeço às instituiç̋es abaixo relacionadas por minha formacăo profissional, bem como pelas facilidades oferecidas para a execucăo desta pesquisa:

Universidade de Săo Paulo - USP

Centro de Energia Nuclear na Agricultura - CENA

Escola Superior de Agricultura "Luiz de Queiroz" - ESALQ

Instituto de Pesquisas Energéticas e Nucleares - IPEN

Cooperativa de Produtores de Cana, Acúcar e Alcool do

Estado de Săo Paulo Ltda. - COPERSUCAR

Agência Internacional de Energia Atômica - AIEA 
SUMARIO

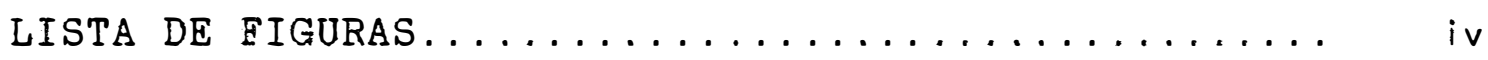

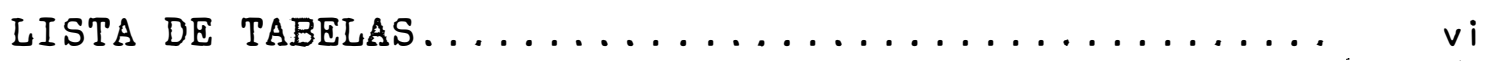

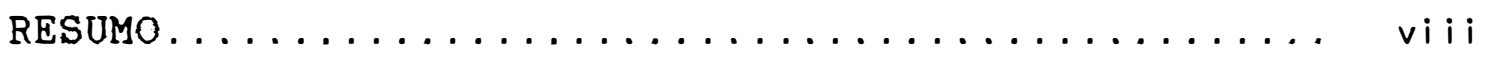

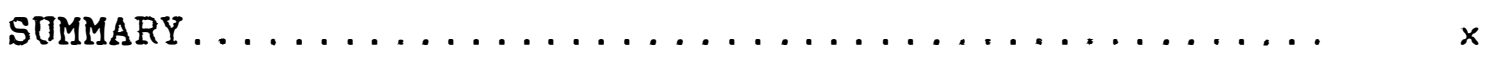

1. INTRODUÇAO $\ldots \ldots \ldots \ldots \ldots \ldots \ldots \ldots \ldots \ldots \ldots \ldots$

2. ATIVAÇO NEUTRÔNICA : EUNDAMENTOS.......... 10

3. METOdOLOGIA....................... 26

3.1. Primeira etapa................ 26

3.2. Segunda etapa................. 28

3.3. Terceira etapa................. 32

3.4. Irradiaçäo das amostras ........... 33

3.5. Deteç̨ӑo................... 34

3.6. Análise química................ 36

3.7. Instrumentaçăo $\ldots \ldots \ldots \ldots \ldots \ldots \ldots \ldots \ldots . . \ldots 7$ 
3. 8. Determinaçăo da eficiência do sistema detector

3. 9. Determinaçăo da atividade inicial..........

3.10. Determinação do fluxo de nêutrons...........

4. RESULTADOS E DISCUSSAO

4.1. Calibraça do sistema detector..........

4.2. Eficiência de deteccăo............

4.3. Fluxo de nêtrons.................

4.4. Atividades e massas...............

4.4.1. Primeira etapa..............

4.4.2. Segunda etapa...............

4.4.3. Terceira etapa..............

4.5. Escândio como tracador .............

5. Conchusoes $\ldots \ldots \ldots \ldots \ldots \ldots \ldots \ldots \ldots \ldots$

REEERENCIAS BIBLIOGRAEICAS ........... 
1. Correlaçáo entre quantidades adicionadas de solo em porcentagem da matéria seca da mistura de cana e solo e os teores encontrados de escândio.......

2. Correlaçăo entre quantidades adicionadas de solo em porcentagem da matéria seca da mistura de cana e solo e os teores encontrados de háfnio........

3. Correlacăo entre quantidades adicionadas de solo em porcentagem da matéria seca da mistura de cana e solo e os teores encontrados de samário.......

4. Correlacăo entre quantidades adicionadas de solo em porcentagem da matéria seca da mistura de cana e solo e os teores encontrados de európio........

5. Correlaçáo entre quantidades adicionadas de solo em porcentagem da matéria seca da mistura de cana e solo e os teores encontrados de lantânio....... 
6. Correlaçáo entre os teores de escândio e de ferro encontrados nos dez solos analisados.......... 81

7. Correlaço entre os teores de escândio e os valores da fraça argila nos dez solos estudados. 
1. Coleta e identificaçáo das amostras de solos, realizadas pela Copersucar..............

2. Resultados (em porcentagem) da análise textural das amostras de solo, efetuada pela Copersucar...

3. Valores de eficiência $(\epsilon \pm \sigma \epsilon)$ para o sistema detector, calculados para as energias dos radionuclideos usados como padrós, segundo

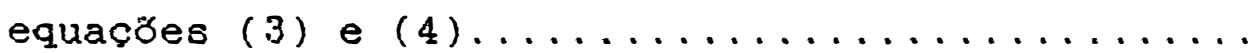

4. Resultados dos teores de ferro das amostras de solo e de cana da segunda etapa.............

5. Valores calculados dos fluxos de nêtrons (1012 n.cm. $\mathrm{s}^{-1}$ ) através dos fotopicos de $59 \mathrm{Fe}$, para as dez amostras de solo da segunda etapa, conforme item $3.10 \ldots \ldots \ldots \ldots \ldots \ldots \ldots \ldots \ldots \ldots$ 
6. Valores calculados dos fluxos de nêutrons (1012 n.cm. -1) $^{-1}$ recebidos pelas amostras da curva de adicáo de solo da terceira etapa, com as respectivas massas irradiadas de ferro $(\mu g) \ldots$.

7. Teores obtidos dos elementos $\left(\mu g \cdot g^{-1}\right)$ nas

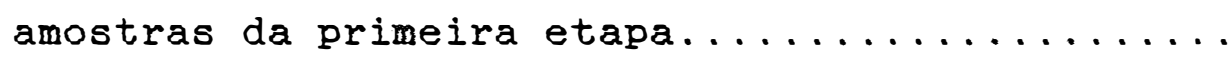

8. Análise da regressäo entre o solo adicionado à cana e os teores dos elementos analisados nas amostras da primeira etapa...............

9. Teores dos elementos encontrados nas amostras de solos $(\mu g . g-I)$ da segunda etapa...........665/66

10. Teores obtidos dos elementos $\left(\mu \mathrm{g} \cdot \mathrm{g}^{-1}\right)$ nas amostras da curva de adicá de solo da terceira

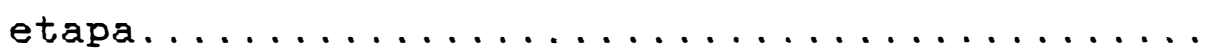

11. Análise da regressăo entre o solo adicionado à cana e os teores dos elementos analisados nas amostras da terceira etapa.............. 
AVALIAÇO DO TEOR DE SOLO EM CARREGAMENTOS DE CANA-DEAÇOCAR POR RADIOATIVIDADE INDUZIDA

Autora: ELISABETE A. DE NADAI EERNANDES Orientador: Prof. Dr. EPAMINONDAS S. B. EERRAZ

RESUMO

No processo de corte e carregamento da canade-açúcar, quantidade significativa de solo é carreada com os colmos. O aprimoramento tecnológico da colheita tem reduzido os teores de terra nos carregamentos para niveis da ordem de 1\%. Para identificar esses baixos níveis de solo que acompanham a cana, estudaram-se os elementos presentes no solo mas ausentes na cana, de modo que atuassem como traçadores do nivel de impurezas minerais.

Em dez usinas do Estado de Săo Paulo, com tipos variados de solos, foram amostradas a terra do horizonte superficial bem como os colmos de cana-deaçúcar da variedade SP 70-1143. As amostras foram irradiadas por nêutrons térmicos em reator nuclear e a radioatividade induzida medida por espectrometria gama de alta resoluçăo, com detector de germânio hiperpuro. Para a avaliaçăo das características analiticas do método, a amostra de solo com os mais baixos teores dos elementos 
determinados foi misturada em proporcós crescentes a cana limpa, desintegrada e seca, sendo o material tambèm irradiado para posterior detecçăo.

Os resultados obtidos para as dez amostras de solo indicaram grande variabilidade na concentraçăo dos elementos como escândio, európio, háfnio, lantânio, samário, etc. Para as dez amostras de cana-de-açucar os teroes de escândio situaram-se ao nivel do limite de detecçáo $(\approx 3 \mathrm{ppb})$, demonstrando ser um elemento de absorçăo năo significativa pelas plantas.

A análise da regressăo entre teores de solo adicionados à cana e os elementos determinados mostrou melhor correlaçăo para o escândio. Utilizando-se este elemento como traçador, é possivel detectar o solo na matéria-prima com precisăo da ordem de 500 g por tonelada de cana ou $0,05 \%$. A reprodutibilidade obtida nas diversas séries de detecçăo do escândio revelou que a determinaçăo do teor de solo na amostra pode ser feita após dez dias do final da irradiaçăo das amostras no reator.

Os teores de escândio no solo apresentaram significativa correlaçăo linear com a porcentagem de ferro. Confrontado com o teor de argila, o escândio resultou em correlaçăo linear somente dentro de certos Iimites, sugerindo eesquisas complementares. 
EVALUATION OF SOIL CONTENTS IN SUGARCANE LOADING USING INDUCED RADIOACTIVITY

Author: ELISABETE A. DE NADAI EERNANDES Adviser: Prof. Dr. EPAMINONDAS S.B. FERRAZ

SUMMARY

When sugarcane is cut and taken to the sugar and alcohol mills, a significant quantity of soil is loaded with the stalks. This content has been reduced to $1 \%$ due to improvement in harvesting methods. Elements present in soil but not in sugarcane have been studied to act as tracers in the determination of unwanted minerals.

Several different soil types at superficial horizon were sampled at ten sugar and alcohol mills in the State of Săo Paulo, as well as sugarcane stalks of the SP 70-1143 variety. The samples were irradiated by thermal neutrons in a nuclear reactor and the induced radioactivity measured by high resolution gamma ray spectrometry, with an hyperpure germanium coaxial detector. To evaluate the analytical characteristics of the method, the soil sample showing the lowest content of the determined elements was mixed, in increasing 
proportion, to the clean sugarcane, and the material irradiated for firther detection.

Results obtained with the ten soils samples indicate great variability in the concentration of elements, such as scandium, europium, hafnium, lanthanum, samarium, etc. Scandium levels of the ten sugarcane samples were at detection limit $(\approx 3$ ppb) showing that the absorption of this element by the plants is not significant.

In regression studies of soil levels and the measured elements the best correlation was found for scandium. Using this element as tracer in sugarcane it is possible to evaluate soil content with $0.05 \%$ accuracy (500 $g$ per ton of cane). The reproducibility of measured radioactivity for Sc revealed that the assessment of soil in cane samples can be made ten days after irradiation.

Significant linear correlation was observed for Sc and Fe for the ten soil samples analysed. Correlation of Sc to clay amounts was linear only up to certain limits, suggesting that further research is necessary. 
1. INTRODUCAO

Para fins industriais, a cana-de-acúcar vem sendo cultivada em praticamente todos os estados do pais, porém $82 \%$ da área canavieira encontra-se distribuida em apenas cinco deles (Så Paulo-48\%, Pernambuco - 12\%, Alagoas - 11\%, Minas Gerais - $6 \%$ e Rio de Janeiro - 5\%). Pelo fato desta distribuiço se dar em duas regióes climáticas distintas, a colheita de cana-de-acúcar é realizada nos meses de outubro a abril e de maio a novembro, nas regióes Norte-Nordeste e Centro-Sul, respectivamente, tornando o Brasil o unico grande produtor mundial de acúcar e álcool durante $\circ$ ano todo (EERNANDES \& IRVINE, 1987).

A diversificaçágo da indistria acucareira para a alcooleira foi intensificada no auge da crise do petróleo em 1973. Inicialmente, pelo aproveitamento do potencial de moagem das usinas de acícar existentes, o 
etanol era produzido e adicionado à gasolina na proporcăo de $20 \%$. Posteriormente, a necessidade de grandes volumes exigiu a construcăo de destilarias autônomas, designadas à producăo de etanol diretamente do caldo de cana-de-aciácar.

Nos últimos dez anos, a produtividade da canade-acúcar tem progressivamente aumentado, fato atribuido à introducăo de novas variedades e ao desenvolvimento de moderna tecnologia agronômica e industrial. o Brasil é atualmente um dos maiores produtores mundiais de cana-deacúcar. Apesar de produzir $25 \%$ da cana-de-acúcar mundial, esta abrangeu em 1986, apenas $8 \%$ dos 52 milhôes de hectares cultivados, ocupando o quinto lugar entre as principais culturas. Anualmente, cerca de 250 milhôes de toneladas de cana săo processados, $30 \%$ destinado à producáo de acúcar e 70\% à de álcool. o Estado de Săo Paulo é o principal produtor, respondendo com 50\% da lavoura canavieira brasileira, além de sediar também as usinas de maior produtividade agroindustrial.

A partir dos anos 60 , a expansăo da área de plantio, juntamente com alteracbes sociais desencadeadas no setor rural, resultou na intensa mecanizacão da cultura. A substituicăo do carregamento manual pelo mecânico, através de garra hidráulica, alterou substancialmente a quantidade de impurezas incorporadas a 
materia-prima. Os teores de terra elevaram-se de valores inferiores a $0,2 \%$ para 1 a $5 \%$ (BRAUNBECK \& BANCHI, 1988).

Com o intuito de identificar e medir esses teores em áreas canavieiras de Sáo Paulo e do Paraná, as cargas de 512 caminhöes de cana carregados mecanicamente foram integralmente analisadas, procedendo-se à quantificąăo manual das impurezas presentes (FERNANDES \& OLIVEIRA, 1977). Da amostragem total de aproximadamente 5000 toneladas de cana, quantidades entre 1,6 a 2,8\% eram constitufdas de impurezas minerais.

Processos de lavagem de cana tiveram que ser introduzidos no setor industrial para remocáo das impurezas minerais, exigindo a criacăo de sistemas complementares de tratamento de água, com a finalidade de evitar poluicăo ambiental pelas águas residuais.

Por outro lado, o rendimento industrial das usinas de aqúcar e destilarias de álcool tem como dependência primária a qualidade da matéria-prima processada. Torna-se evidente, entăo, que um dos fatores preponderantes no comprometimento desta qualidade é a quantidade de impurezas advindas do corte, carregamento e transporte da cana-de-açucar da lavoura à usina. 
- Considerando-se que do total de cana industrializada durante uma safra no Brasil, $0,5 \%$ seja constituido de impurezas minerais oriundas principalmente do solo, tem-se 1,25 milhóes de toneladas de terra que sáo transportadas e incorporadas ao processo.

Os custos de manutençăo de uma usina săo significativamente afetados pela presenca de impurezas no fornecimento de cana indicados, entre uma série de fatores, pela alimentacăo reduzida e conseqiante perda de capacidade e eficiência de moagem, além da depreciaçáo de parâmetros tecnolbgicos finais como alteraç̄es no brix, pol \% cana, teor de fibra, recuperacáo de acícar, etc. 0 bagaco, utilizado como combustivel alternativo em caldeiras, pode năo queimar adequadamente devido à presenca de minerais que alteram $\circ$ poder calorffico. Assim, um valor aparentemente satisfatorio de fibra pode năo ser realmente apropriado para manter vapor suficiente sem combustivel complementar (LAMUSSE \& MUNSAMY, 1979).

A fibra industrial, considerada como a fibra real mais impurezas, exerce grande influencia no processo de fabricaçăo do açucar e do álcool. Quanto mais alto o seu indice, maior será o desgaste de equipamentos de preparacăo e moagem e menor a extraçá, vindo a resultar em depreciaça da pol \% cana, que $e$ o paràmetro mais 
relevante na sistemática do pagamento de cana pelo teor de sacarose (GONÇALVES, 1987).

Além disso, o solo aderido à cana pode provocar desgaste acentuado nas facas e martelos durante 0 estágio de preparaça, nos cilindros das moendas na fase de extracăo do caldo, bem como de condutores e demais partes que entram em contacto com a matéria-prima em processamento.

Apesar do conhecimento de todos esses efeitos, - assunto ainda năo foi suficientemente investigado sob condiczes industriais. Os métodos existentes para a quantificacăo destas impurezas requerem um exame fisico do fornecimento de cana, amostragem e separacăo manual dos colmos dos constituintes restantes da amostra (ponteiros, palhas, solo, pedras, pedacos de metais, etc.) e posterior pesagem (EERNANDES \& OLIVEIRA, 1977; BURGHER \& NIX, 1979).

Na prática, areia e solo em cana năo podem ser medidos como tais, entăo, assume-se que o valor cinzas \% cana é uma medida da extensăo de sua presenca. E evidente que o conteúdo de cinzas do solo será menor que a massa de solo, devido a perdas de umidade e matéria organica durante a calcinąăo (LAMUSSE \& MUNSAMY, 1979). Este método inferencial de cinzas dos varios fluxos do processo 
dentro da usina tem sido bastante discutido (MULLER et alii, 1982; NEETHLING, 1982).

O método das cinzas foi também utilizado por BROKENSHA \& MELLET (1977) para estimar niveis de solo em cana preparada. Com este procedimento, o conteúdo de solo da amostra de cana é tido como as cinzas residuais da incineraçăo da amostra sob condicóes especificas, deduzindo-se o valor correspondente às cinzas da propria cana. Os valores encontrados de cinzas \% cana livre de solo variaram de 0,4 a $1,2 \%$, sendo dependentes de fatores como tipo de solo no qual a cana foi cultivada, uso de fertilizantes, teor de umidade, etc. Desse modo, a quantidade de solo em um carregamento de cana năo pode ser obtida diretamente dos valores de cinzas \% cana.

Entretanto, ambos os métodos descritos sáo operacionalmente laboriosos e extremamente lentos para serem implantados em controle de qualidade. Neste aspecto, técnicas nucleares mais avançadas vêm sendo empregadas com sucesso em vários pontos do sistema de produçáo. AYLMER \& HOLMES (1981) desenvolveram um método para avaliar o conteúdo de solo em amostras de $10 \mathrm{~kg}$ de cana-de-acícar desintegrada, procedentes de regibes com o mesmo tipo de solo. Pela ativacăo do silfcio e aluminio constituintes do solo com néutrons rápidos e têraicos, respectivamente, de 
uma fonte de $10 \mathrm{Ci}$ de $241 \mathrm{Am}-\mathrm{Be}$ e detecção da radiaçáo gama de $1,78 \mathrm{MeV}$ do $28 \mathrm{Al}$ formado em ambas as reaçöes, teores de solo entre 0,3 e $2,5 \%$ por peso foram medidos com $0,1 \%$ de precisáo. LOUGHRAN et alii (1983) tornaram este método automatizado, de forma que uma amostra era irradiada enquanto outra irradiada anteriormente já estava sendo detectada. Este arranjo experimental possibilitou a análise das amostras de cana-de-açúcar de forma continua, reduzindo o tempo efetivo de análise de 12 para 7,5 minutos, com precisăo aproximada de $1 \%$ em condicóes de rotina.

No Brasil, os trabalhos pioneiros relacionados à determinaça de solo em cana-de-açúcar por meio de técnicas nucleares foram desenvolvidos por NASCIMENTO EQ et alii (1986 a), através da ativaçäo neutrônica de amostras de cana (24 g) contendo $2 \%$ de solo, com fonte radioativa de $252 \mathrm{Cf} \quad(6,27 \mathrm{mCi} ; 11,7 \mu \mathrm{g} ; \quad 2,69.107$ nêutrons.cm $\mathrm{cm}^{-1}$ ) e deteccăo da atividade induzida no aluminio constituinte da matriz do solo, pela reaço $27 \mathrm{Al}(\mathrm{n}, \mathrm{Y}) 28 \mathrm{AI}$.

o emprego da análise por fluorescência de raios $X$ com dispersăo de energia e excitaçáo por tubo de raios $\mathrm{X}$ (anodo de tungstênio, alta tensäo $30 \mathrm{kV}$, corrente eletrica $34 \mathrm{\mu A}$; filtro de cobre) mostrou-se eficaz na 
detecção năo destrutiva, instrumental e simultânea de Ee e Ti em amostras de cana preparada, contaminadas com $2 \%$ de solo (NASCIMENTO EQ et alii, 1986 b).

Nas últimas duas décadas tem-se visto rápido desenvolvimento dos métodos instrumentais de análise, os quais vêm substituindo os tradicionalmente em uso nos mais diferentes campos cientificos, tornando possível a automaçăo de determinaços anteriormente impraticáveis de serem realizadas em caráter de rotina. A rapidez com que estas técnicas instrumentais têm se incorporado aos laboratórios relacionados à agricultura e ambiente, nos quais se focalizam principalmente as amostras de solos e plantas, é influenciada em grande parte pelos altos custos de implantaçáo de tecnologia mais avançada, além da vigência de certas leis que regem que determinadas análises devem ser realizadas de um modo particular.

No que se refere à quantificacăo do teor de impurezas minerais, especialmente terra, que acompanha a matéria-prima às usinas de acúcar e álcool, ainda năo se tem um método especificado e recomendado, que possa ser rotineiramente utilizado, avaliado pelas caracteristicas de custo, simplicidade, velocidade e sensibilidade. 
Recentes avanços no desenvolvimento de tecnologias alternativas de carregamento para reducko de terra na matéria-prima incluem novos tipos de carregadoras mecanicas como, por exemplo, a carregadora continua e a carregadora tradicional com garra rotativa. Com esse aprimoramento, os teores de terra foram gradativamente reduzidos a valores inferiores a $1 \%$, semelhantes aos observados no carregamento manual (BRAUNBECK \& BANCHI, 1988). Para atender às necessidades analfticas de niveis assim reduzidos, hâ que se trabalhar com um método que diferencie teores minimos de terra, permitindo avaliar com precisåo as caracteristicas individuais dos novos tipos de carregadoras introduzidas.

A proposicăo deste trabalho relaciona-se ao desenvolvimento de metodologia capaz de quantificar a presenca de solo incorporado à cana-de-acicar, usando a técnica analitica nuclear de ativaço neutronica, mais sensfvel que as convencionais. Pela irradiaço da materia seca, resultante de amostras de cana-de-acicar com impurezas, por nêtrons têrmicos de um reator nuclear, pretende-se detectar a radioatividade induzida nos nuclideos ativareis que caracterizam proporcionalmente o solo na matéria-prima. 
2. ATIVACEO NEUTRONICA : EUNDAMENTOS

Assim como todos os metodos fisicos de anälise elementar, a ativacăo neutrónica depende da medida de uma propriedade especifica que é inica ao elemento e cuja magnitude é confiavelmente relacionada à quantidade do elemento presente na amostra. O principio consiste simplesmente em induzir radioatividade no material constituinte da amostra e medir, entáo, a radiaçáo especifica aos nuclideos dos elementos.

Quando um material é bombardeado com nêtrons, particulas carregadas ou fitons, parte dos constituintes pode se converter por reacbes nucleares a nuclideos radioativos do mesmo ou de outro elemento. No caso da irradiacăo neutrónica, normalmente, a conversáo se efetua para um nuclideo do mesmo elemento e o excesso de energia 
e Iiberado sob a forma de raios gama "prontos", conforme esquematizado a seguir:

$$
z+{ }^{n} \mathrm{n}={ }_{z}^{+1} \mathrm{X}+Y
$$

o novo nuclídeo é quase sempre radioativo e a medida de sua atividade proporciona uma estimativa da quantidade do elemento $X$ presente no material irradiado.

Cada nuclideo do elemento tem probabilidade especifica para capturar nêtrons de determinada energia. Esta probabilidade de captura tem a dimensăo de área é chamada seçăo de choque de absorçăo, expressa em barn, unidade correspondente a $10-24 \mathrm{~cm}^{2}$. A atividade induzida ao final da irradiação pode ser calculada pela equaçăo:

$$
A_{0}=m \cdot \theta \cdot \sigma \cdot N \cdot \Phi \cdot\left(1-e^{-\ln 2 \cdot t / T}\right) / M
$$

onde

$A_{0}=$ taxa de desintegracazo, em becquerel (dps)

$m$ = massa do elemento irradiado (grama)

$\theta$ = abundância isotópica natural do nuclideo (fraç⿰丿)

$\sigma=$ seçăo de choque de absorcáo $\left(\mathrm{cm}^{2}\right)$ 


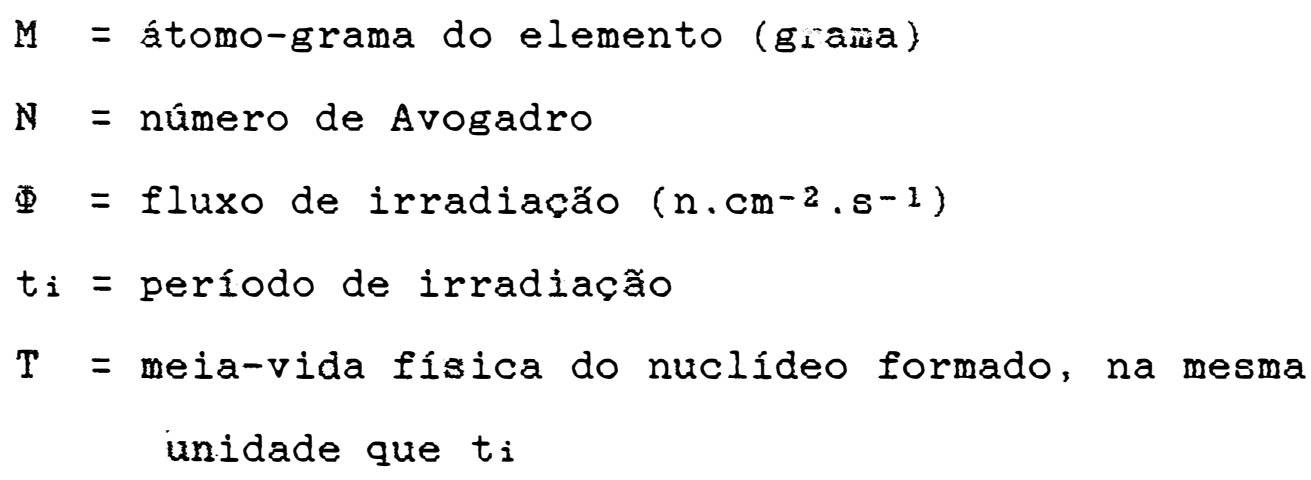

Decorrido um periodo de decaimento ou resfriamento $t_{r}$, a atividade induzida decresce exponencialmente de acordo com a equaço:

$$
A=A_{0} \cdot e^{-\ln 2 \cdot t_{r} / T}
$$

Uma consequiência da relaģa mostrada na equaçäo 1 é que a radioatividade induzida aumenta linearmente para baixos valores de $t_{i}$ com referência à meia-vida $\mathrm{T}$, sendo limitada à atividade de saturaçăo para um valor infinito de $t_{i}$, quando as taxas de produçăo e de decaimento da atividade estäo em equilibrio. Após um período de irradiaçăo igual a uma meia-vida, haverá metade da atividade de saturaçăo.

Para se ter idéia da sensibilidade alcançada pela análise por ativaçă, pode-se considerar um nuclideo hipotético com alguns parametros nucleares tipicos. A 
atividade induzida em um nanograma de um elemento monoisotópico de átomo-grama $M \approx 100 \mathrm{~g}$ e seção de choque de 0,1 barn, quando irradiado por período equivalente a uma meia-vida, em fluxo de nêutron de $1014 \mathrm{n} \cdot \mathrm{cm}^{-2} . \mathrm{s}^{-1}$, é de aproximadamente 30 becquerel $(\approx 0,8 \mathrm{nCi})$. Se este nuclídeo emitir raios gama com energia de $800 \mathrm{keV}$ e intensidade de emissăo de $100 \%$ e a eficiência de um detector de germânio para este fotopico for de $2 \%$, entžo, serão obtidas 37 contagens por minuto, valor bastante diferenciado da radiaçăo de fundo. Dessa forma, este nivel de radioatividade seria discriminado e medido através da técnica instrumental, com considerável precisăo e sensibilidade, sem necessidade de recorrer a métodos radioquímicos de separaça.

A maior parte dos elementos do sistema periódico possui nuclídeos com propriedades de ativaçăo e decaimento, de tal forma que a técnica de ativaça por nêtrons pode ser utilizada na análise de uma variedade ampla de matrizes, näo somente para a determinaçáo de elementos traços como também dos demais constituintes.

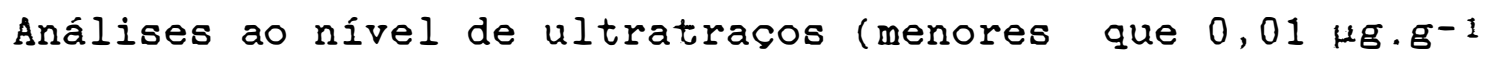
ou equivalente) sáo particularmente suscetiveis a erros por contaminaçăo, mostrando-se a análise por ativacaao adequada a esta finalidade. 
Neste meio século de existência, a análise por ativaçăo tem sido aplicada em estudos ambientais, geológicos e geoquímicos, ciências biológicas, médicas e correlatas, especialmente quando pequenas amostras săo disponiveis, empreendimentos industriais, investigações arqueológicas, criminalística e outros (HEYDORN, 1988).

A ativaçăo neutrônica é também empregada como método de avaliaçăo independente de outros netodos instrumentais ou mesmo com propósitos de padronizaçáo de técnicas rotineiramente empregadas. Suas caracteristicas de exatidåo, capacidade multielementar, habilidade para avaliar eficientemente a homogeneidade, alta sensibilidade e natureza essencialmente livre de "branco", tornam-na uma ferramenta extremamente útil para certificar materiais de referência (GREENBERG, 1987).

A escolha das particulas ativadoras náo tem mostrado desenvolvimento significativo, com nêtrons ainda dominantes sobre prótons, dêterons, partículas alfa e raios gama (HEYDORN, 1988). Efetivamente, nos processos de ativaçăo descritos na literatura, nêtrons, e em especial os térmicos, têm sido utilizados. Esta particularidade está principalmente relacionada ao fato de grande número de núcleos possuir alta secäo de choque para nêtrons 
térmicos, além do que a induçáo de atividade por nêtrons năo apresenta dificuldades especiais.

0 interesse em elementos ao nivel de traços e ultratracos em biologia, pesquisas ambientais, geologia e tecnologia tem aumentado a necessidade por análises multielementares de grande número de amostras. Face aos recentes desenvolvimentos das técnicas analiticas e à crescente competiçáo entre elas, esta demanda aumentou 0 valor da análise por ativaçáo instrumental năo destrutiva. Devido à relativa simplicidade e inerente seletividade e sensibilidade, a análise por ativaçáo neutrônica ocupa uma das mais importantes posiçöes entre os vários métodos analfticos. Embora o espectro gama resultante das amostras irradiadas seja normalmente complexo, 0 advento dos detectores de alta resoluçáo de germanio, analisadores multicanais de quatro a oito mil canais e computadores "on-line" proporcionaram a possibilidade de análise multielementar sem separacăo química em muitos casos.

- princípio da análise por ativaçäo instrumental consiste em se evitar separacöes quíicas e fazer uso de uma propriedade nuclear, a energia dos raios gama associados, como fator discriminante. Sua aplicaça fica, portanto, limitada a matrizes em que a maior parte da ativaçăo ocorre entre os elementos menores e tracos 
presentes. Um exame das seços de choque de ativaço dos nuclideos dos elementos na tabela periódica mostra pouca relaçáo entre eles $e$ as propriedades quimicas, ao contrário dos parâmetros normalmente encontrados nos métodos de discriminaçäo química (SALMON \& CAWSE, 1986).

No presente estágio da espectrometria gama, grande variedade de materiais pode ser analisada náo destrutivamente com um número limitado de irradiaç⿸es e medidas, fornecendo resultados quantitativos para 10 a 35 elementos e limites de deteccáo para os restantes. Relativamente à ativacáo de amostras de solo, os constituintes maiores de baixo número atômico como carbono, nitrogênio, oxigênio, hidrogênio e silicio apresentam baixa suscetibilidade à ativaçäo por nêtrons térmicos, produzindo pouca atividade, enquanto que 0 aluminio propicia a formacăo de apenas um nuclideo, com meia-vida de 2,3 minutos. Contudo, muitos elementos menores e traços têm características favoráveis, sendo facilmente ativados.

Embora a relaça linear entre massa e atividade induzida seja mostrada na equaçăo 1 , o estabelecimento das constantes de proporcionalidade requer conhecimento dos parâmetros experimentais e nucleares. Após a deteçăo das atividades induzidas, as equacós 1 e 
2 permiten em teoria o cálculo da massa (m) do elemento presente na amostra. No caso da análise absoluta, isto é realmente feito, contanto que alguns parâmetros sejam perfeitamente conhecidos, como valor absoluto do fluxo térmico, tempo exato de irradiaçăo, meia-vida, esqueas de decaimento, seção de choque de ativacáo têrmica e calibraçåo do detector (De SOETE et ali1, 1972).

o método direto de análise por ativação baseado na determinaçáo das massas por meio da equacho de ativaçäo, considerado como um método semiquantitativo, apresenta poucos exemplos na literatura. Os problemas geralmente apontados se relacionam às incertezas inerentes às constantes nucleares e às dificuldades em se medir com exatidão fluxos de nêtrons e taxas de desintegraçäo. Por outro lado, em referência ao procedimento relativo normalmente adotado, sáo relatadas vantagens como simplificacăo do trabalho experimental e eliminacão de erros devidos à näo homogeneidade do fluxo de nêtrons no interior da cápsula de irradiação.

- conhecimento mais. preciso das constantes nucleares, associado ao aprimoramerico das técnicas e da instrumentaçåo de detecosko nuclear, levou GIRARDI et alii (1964) a avaliarem a competitividade do método direto com - relativo. Treze elementos foram irradiados e suas 
atividades medidas por espectrometria gama absoluta, as massas sendo calculadas pela equaçáo de ativacáo e comparadas às massas reais dos elementos. Os erros estatísticos náo foram maiores do que os obtidos pelo método relativo, porém os sistemáticos chegaram a $10 \%$ para a maioria das amostras, sendo especialmente atribuidos às incertezas dos esquemas de decaimento e secóes de choques de ativaça.

A exatidão da determinacáo da massa pela utilizaçăo da taxa de desintegraçáo depende da exatidăo dos valores absolutos da seçáo de choque, da integral de ressonância e das variáveis do esquema de decaimento. Um numero importante deles năo é ainda suficientemente conhecido, de modo a permitir seu uso em cálculos absolutos precisos (ADAMS \& DAMS, 1975).

$\mathrm{Na}$ prática, a maneira mais usual de se proceder à análise por ativacăo compreende a irradiacáo simultânea da amostra e referência. Neste método comparativo, uma quantidade conhecida do elemento a ser determinado é irradiada sob condiçóes similares às da amostra. Assim sendo, todos os parâmetros nucleares e de irradiaçáo podem ser tomados como constantes entre amostra e referencia e a razăo das atividades induzidas na amostra e referência, $A_{2}$ e $A r$, pode ser considerada igual à razäo 
das respectivas massas, ma e $\mathrm{mr}$, de acordo com a reiaço:

$$
\text { Aa } / A r=m a / m r
$$

Quando se procede à análise de amostras de solos, por exemplo, a normalizaçáo se refere somente à correçá para diferencas nos tempos de decaimento entre amostra e referência, de tal modo que a razḱo entre a massa de um determinado elemento na amostra de solo e a massa do mesmo elemento na referência seja igual à razão entre as atividades normalizadas do referido elemento no solo e na referência. Para isso, assume-se que tanto amostra e referência foram submetidas a idênticas taxas de nêtrons e que năo tenha ocorrido efeito de sombreamento durante a irradiação.

A análise multielementar, portanto, nem sempre é viável por ativaçăo neutrônica em sua forma clássica, isto é, irradiaçăo e medida de um padrăo para cada elemento a ser determinado. Este procedimento apresenta obviamente algumas desvantagens como preparo, irradiacko e deteccắo de um grande número de padróes, efetuado apenas para os elementos cuja presenca é de antemăo esperada, constituindo-se em tarefa demorada e que pode introduzir erros nas diversas etapas do procedimento. Neste caso, a analise quantitativa bem como o calculo dos limites de 
deteccăo ficam impossibilitados para aqueles elementos cujos padröes năo foram providenciados.

* algumas vezes diffcil assegurar condiçóes de irradiação identicas para amostras e padróes. Problemas podem advir da näo homogeneidade do fluxo de nêtrons ao longo da cápsula de irradiacăo, de efeitos de sombreamento nos padröes, falta de espaco na cápsula de irradiacáo, variacão do fluxo de nêtrons durante repetidas irradiaçöes, etc. (SIMONITS et ali, 1975).

As dificuldades mencionadas podem ser parcialmente eliminadas pelo emprego de materiais bem caracterizados como padroes certificados. O uso destes materiais como padröes é vantajoso somente em casos limitados e sua aplicaçăo restrita ao tempo e custos envolvidos na preparacăo e análises intercomparativas. Algumas vezes, suas propriedades físicas e quimicas tornam seu manuseio inviável, a lém do que a faixa de concentraçăo dos elementos de interesse pode estar ocasionalmente distante daquela da amostra em análise. Para a extensa variedade de amostras analisadas por ativação neutrônica, este tipo de padronização, embora continuamente en desenvolvimento, não encontra aplicacăo generalizada. 
Deve-se entender por método do comparador único a técnica segundo à qual a análise multielementar é realizada pela irradiaçáo e medida de um unico elemento (comparador), ao invés de padröes preparados a partir de massas conhecidas dos elementos a serem determinados. As atividades especificas dos padröes săo calculadas pela multiplicaça da atividade especffica medida do comparador por fatores $k$ experimentais. $N a$ prática, o comparador constitui-se de pequena folha delgada ou mesmo de alguns milimetros de fio de um elemento selecionado ou de uma liga do elemento que, devido às suas pequenas dimensöes, pode ser colocado bastante próximo à amostra durante a irradiaçá assegurando, dessa forma, que a razáo dos fluxos para amostra e comparador seja igual à unidade.

Este método foi primeiramente avaliado por GIRARDI et ali (1965), que observaram exatidăo e precisáo similares àquelas do método relativo. Embora necessário um trabalho experimental laborioso e preciso para se determinar os fatores $\mathrm{k}$, uma vez avaliados, fica eliminada a preparaçăo de padröes em análises subsequientes. Os autores assumiram a constância desses fatores, isto é, răo ocorrem variaçóes nos parâmetios da equaçáo de ativacáo entre o momento da determinaçáo desses valores e aquele da análise da amostra. O método pode ser usado em reatores operacionalmente estáveis e bem termalizados, com controle 
periódico das condiçöes de irradiacăo e de medidas. Apesar de terem investigado os efeitos de possiveis variaçßes na razäo dos fluxos térmico e epitérmico sobre os fatores $k$, nenhuma correcăo foi apresentada para se utilizar as demais posiçöes de irradiaçăo.

Estendendo a aplicabilidade deste método a outras posiçöes de irradiaça, De CORTE et alii (1969) introduziram a conversäo dos valores de $k$ con relacăo seçäo de choque efetiva, demonstrando que os fatores determinados na posicăo tomada como referência (onde a razäo dos fluxos térmicos e epitérmicos é bem conhecida) podem ser reavaliados para qualquer posicăo analftica.

SIMONITS et ali (1975) avaliaram os diferentes métodos comparadores até entäo utilizados. 0 método baseado em fatores $k$ experimentalmente determinados parece ser o mais conveniente e exato para usos gerais. Com a finalidade de simplificar o trabalho experimental, mantendo exatidäo similar, introduziram valores ko, independentes das condiçöes de irradiaça e de medidas, considerados como constantes nucleares compostas. E um método alternativo ao absoluto, eliminando muitas incertezas introduzidas pelo uso de dados nucleares absolutos ambíguos, além de combinar a simplicidade dos métodos absolutos com aproximadamente a mesma exatidå 
obtida pelos relativos. Uma vantagem adicional se refere à possibilidade de utilizaçáo de qualquer elemento como comparador, para as condiçöes mais variadas de irradiacáo.

Na avaliaçăo final da exatidăo do metodo de padronizaçáo ko proposto, a incerteza total nos resultados da análise ocasionada pelos parâmetros de relevância é menor que $4 \%$, em condiços náo muito extremas de irradiaçăo e deteccáo para reacóes $(n, \gamma)$. O método $\epsilon$ comprovadamente eficaz quando comparado à padronizaçăo relativa clássica, onde problemas práticos também eståo presentes, como o preparo de padrăo de composicăo exatamente conhecida, erros sistemáticos devido à năo estequiometria dos compostos ou mesmo pela pipetagem de pequenos volumes (De CORTE et alii, 1987).

Outro método padráo de relevância compreende o uso de um elemento constituinte da amostra como padráo interno. Um procedimento de radioativaçáo com padronizacáo interna foi proposto por LELIAERT et alii (1958), para a determinaçáo de vanádio em amostras de acos por ativaçáo com nêutrons térmicos. O manganês presente na amostra, cujo teor era exatamente conhecido, foi usado como padråo interno, permitindo correçóes com exatidáo das irregularidades dos fluxos de nêtrons entre amostra e referência. Qualquer diferença na atividade do manganês 
por unidade de massa da anostra pode ser atribuída à năo homogeneidade do fluxo de nêtrons ou a diferente sombreamento de nêtrons. óbvio que a atividade especifica do vanádio na amostra correspondente diferirá da mesma fraçăo. A exatidăo do método foi testada em padröes de referência, apresentando excelente concordancia com os valores certificados. Para pequenas quantidades de vanádio, a precisăo foi comparável às obtidas em análises químicas. A eficácia da padronizaça interna foi tambèm demonstrada por HOSTE et alii (1961) na determinaço de manganês em ligas metálicas, utilizando-se o ferro e o cobalto presentes na amostra como padröes internos.

De forma generalizada, a literatura mostra que - desenvolvimento da análise instrumental multielementar gerou necessidade crescente de se evitar padronizaçöes demoradas, este fato excluindo 0 uso de padröes individuais para cada elemento a ser determinado. Um dos caminhos se refere ao uso de monitores de fluxos, incluindo dois ou três nuclideos para avaliaçáo dos fluxos térmicos e epitérmicos. Para tal, há exigência da exatidầo dos dados de medida da eficiência do detector, estabilidade temporal do fluxo de nêtrons, além de controles periódicos (SIMONITS et alii, 1987). Outra possibilidade é a utilizaçăo de uma mistura de elementos como padrăo mltielementar. Diversas substancias naturais 
cono rochas e materiais biológicos têm sido propostas, após homogeneizaçăo e cuidadosa análise interlaboratorłal (NADKARNI \& MORRISON, 1978). Entretanto, estes padröes săo de interesse em análises de amostras similares, nåo encontrando aplicaçăo universal.

Ainda com referência ao uso de padröes em ativaçăo neutrônica, é comum perder-se precisăo na medida do fotopico de interesse por estar situado em regiáo de alta radiaçáo de fundo, inerente à matriz do próprio padra, ou superposto a outro fotopico. Para contornar tais dificuldades, têm sido introduzidos padröes sintéticos multielementares, cuja composiçăo é otimizada para se obter espectros com o mínimo de erros sistemáticos e estatisticos. Matrizes metálicas (aluminio) e polímeros orgânicos (fenolformaldeído) têm sido utilizados como material básico na produçăo de padröes multielementares (ROUCHAUD et alii, 1987).

A literatura analisada mostrou controvérsia quanto à utilizaçăo do método absoluto ou do relativo em análises por ativaçăo neutrônica. Desde a década de 50 , quando as discussöes concermentes ao assunto foram mais amplamente difundidas, até presentemente, ainda năo se chegou a um procedimento de uso generalizado. 
3. METODOLOGIA

A parte experimental foi conduzida em três etapas consecutivas, sendo que a primeira serviu para delinear as subsequientes.

3.1. Primeira etapa

Nesta etapa, foram escolhidas três amostras de solo da camada superficial de 0 a $20 \mathrm{~cm}$, tendo como parámetro de diferenciaça entre elas a variabilidade textural (argila, barro-argiloso e barro-arenoso). Depois de secas ao ar, as amostras foram destorroadas, moidas e passadas em peneiras de $2 \mathrm{~mm}$ ( $Q$ mesh), sendo a seguir acondicionadas em recipientes vedados. Uma aliquota de 100 mg de cada amostra foi pesada diretamente nas cápsulas de irradiaça $(i t e m 3,4)$. 
Foram coletados vinte colmos de cana-de-açucar da variedade SP 71-1406, descartando-se a parte terminal do internódio basal e os ponteiros. Antes de se proceder à desintegraça, procurou-se retirar toda a materia estranha aderida à superfície dos colmos. Da amostra desintegrada, parte foi destinada à obtencăo do teor de umidade e o restante separado em quatro porçóes de $1000 \mathrm{~g}$. A cada uma dessas subamostras foram adicionados e distribuídos uniformemente 5,10 e $20 \mathrm{~g}$ do solo de textura barroargiloso, ficando uma sem adiçăo de solo. Após a homogeneizaça e secagem em estufa a $105^{\circ} \mathrm{C}$ ate massa constante, o material foi pulverizado moinho wiley (20 mesh). Eoram pesados $100 \mathrm{mg}$ diretamente nas cápsulas de irradiaçáo, com dimensőes de $9,2 \mathrm{~mm}$ de diâmetro e 8,7 mm de altura, vedadas hermeticamente.

Durante a detecça da radioatividade induzida, a amostra composta unicamente de cana desintegrada (sem adicăo de solo) indicou a presenca de determinados elementos constituintes do solo, evidenciando a năo eficácia do procedimento de limpeza adotado. Desse modo, na segunda etapa, foi dispensada maior rigorosidade à limpeza das amostras de cana. 
3.2. Segunda etapa

Um levantamento das áreas canavieiras efetuado a nivel regional possibilitou o planejamento dos locais de coleta de amostras para esta etapa. A variedade SP 70-1143 foi escolhida por ser amplamente disseminada no Estado de Sao Paulo (MACHADO Jr., 1986). Em 1987, alcancou o segundo lugar em área plantada da regiáo centro-sul do pais, com tendência a ocupar o primeiro em 1988. Este fato permitiu amostragem significativa dos diferentes tipos de solos cultivados com cana-de-acúcar.

A amostragem de solos foi efetuada em três regibes distintas do Estado, compreendendo as Usinas Santa Cruz (Municipio de Capivari), Săo Luiz (Municipio de Piraçununga) e Porto Eeliz (Município de Rafard), totalizando dez tipos de solos, classificados de acordo com BARBIERI \& POLI, 1984 (Tabelas 1 e 2). Amostras representativas do solo superficial, sem cobertura morta, foram retiradas até cinco centímetros de profundidade, em torno dos colmos amostrados. Alem do tratamento usual de secagem, moagem e peneiragem, as amostras foram finamente pulverizadas em almofariz de ágata atè avingir granulometria inferior a $250 \mathrm{\mu m}$ (60 mesh) sendo, entao, uma parcela destinada à irradiaçăo e outra à análise química elementar (item 3.6 ). 
Tabela 1. Coleta e identificaçó das amostras de solo, realizadas pela Copersucar.

\begin{tabular}{ccccc}
\hline Amostra & Solo & Usina & Fazenda & Talhăo \\
\hline 1 & CB & Santa Cruz & Matáo & 31 \\
2 & PVA & Santa Cruz & Monte Alegre & 76 \\
3 & PVE & Porto Feliz & Barnabé & C12 \\
4 & LVA & Porto Feliz & Boa Vista & C29 \\
5 & LVA & Porto Feliz & Sobradinho & D17 \\
6 & LR & Săo Luiz & Sáo Luiz & 17 \\
7 & LVE & Săo Luiz & Săo Luiz & 108 \\
8 & LVA & Săo Luiz & Santa Maria & 155 \\
9 & TRE & Sáo Luiz & Lavrinha & 31 \\
10 & PVA & Porto Eeliz & Barnabé & C4 \\
\hline
\end{tabular}

Localizacăo ne Estado de Săo Paulo:

Usina Santa Cruz entre Piracicaba e Capivari

Usina Porto Feliz entre Rafard e Porto Feliz

Usina Sao Luiz entre Piracununga e Santa Crua das Palmeiras 
Tabela 2. Resultados (em porcentagem) da analise textural das amostras de solos, efetuada pela Copersucar.

Amostra Areia Areia Areia Limo Argila Classificaca Fina Grossa Total Textural

\begin{tabular}{rrrrrll}
\hline 1 & 26,98 & 19,02 & 46,00 & 36,85 & 17,15 & Barro \\
2 & 44,99 & 32,46 & 77,45 & 8,60 & 13,95 & Barro Arenoso \\
3 & 22,55 & 8,96 & 31,51 & 18,69 & 49,80 & Argila \\
4 & 17,56 & 34,21 & 51,77 & 9,72 & 38,50 & Argila Arenosa \\
5 & 42,53 & 21,02 & 63,55 & 23,40 & 13,05 & Barro Arenoso \\
6 & 16,80 & 9,43 & 26,23 & 30,82 & 42,95 & Argila \\
7 & 31,91 & 7,30 & 41,21 & 19,04 & 39,75 & Barro Argiloso \\
8 & 37,23 & 39,99 & 77,22 & 4,08 & 18,70 & Barro Arenoso \\
9 & 18,69 & 4,58 & 23,27 & 21,03 & 55,70 & Argila \\
10 & 25,77 & 14,19 & 39,96 & 18,19 & 41,85 & Argila \\
\hline
\end{tabular}


Para minimizar $\circ$ efeito do temes morto do detector devido às altas atividades induzidas nas amostras, conforme observado na detecçáo da etapa preliminar, a massa de amostra de solo a ser irradiada foi reduzida à metade, ou seja, $50 \mathrm{mg}$ pesados em cápsulas de $9,2 \mathrm{~mm}$ de diâmetro e $5,7 \mathrm{~mm}$ de altura (item 3.4 ).

Em cada local de amostragem de solo foram coletados dez colmos da variedade SP 70-1143, onde tomouse o cuidado de năo permitir qualquer contacto dos mesmos com o solo, após o corte. Apesar disso, os colmos foram individualmente lavados para se eliminar toda particula aderida à superficie e, em seguida, secos e desintegrados. As primeiras porcoes desintegradas de cada conjunto foram desprezadas, para năo haver contaminacăo entre amostras. Feita a homogeneizaçăo, quatro subamostras de $200 \mathrm{~g}$ de cada amostra foram retiradas e levadas à estufa de circulacăo forcada, a $80^{\circ} \mathrm{C}$, até massa constante. Uma vez secas, foram moidas e recolhidas para recipientes adequados e mantidas em dessecador. Parte dessas amostras foi destinada à análise química elementar para se avaliar os teores de macro e micronutrientes da planta (item 3.6).

Para se aumentar a sensibilidade do método de deteçăo, a quantidade utiizada de matéria seca de cana foi o dobro relativamente à etapa anterior, ou seja, foram 
pesados $200 \mathrm{mg}$ em cápsulas de irradiaçäo, com dimensóes de $9,2 \mathrm{~mm}$ de diâmetro por $11,7 \mathrm{~mm}$ de altura.

3.3. Terceira etapa

Com a finalidade de se estimar o limite de deteçăo e sensibilidade do metodo proposto, foram preparadas amostras de cana com quantidades crescentes de solo. A amostra de solo LVA (número 5, da segunda etapa) foi especialmente selecionada por ter apresentado os mais baixos teores dos elementos escolhidos como tracadores.

Para este estudo, foram pesados $0,5,10,15$, $20,30,40,60,80$ e $1000 \mathrm{mg}$ da amostra de solo (TESA), em frascos apropriados de pesagem e homogeneizaçăo, aos quais foram posteriormente adicionadas quantidades suficientes da matêria seca da cana-de-açúcar vegetada sobre o solo em questäo, para completar $1000 \mathrm{mg}$. Após a mistura desses materiais pela agitacăo repetida dos frascos, com 0 propósito de evitar a deposiçäo das particulas mais densas com o decorrer do tempo, $100 \mathrm{mg}$ foram transferidos para as cápsulas de irradiaçăo. A primeira amostra năo sontinha solo e a última, somente solo. 
3.4. Irradiaçáo das awostras

As cápsulas de plástico de alta pureza, especiais para análise por ativacăo (ATALLA, 1976), permitiram que se fizesse a irradiaça da amostra e posterior deteçăo da radioatividade induzida, sem a necessidade de transferência e manipulaçä de material radioativo. Estas cápsulas preenchidas com as amostras foram envoltas em folhas de aluminio e inseridas em tubos especiais de aluminio denominados "coelhos", de aproximadamente $4,5 \mathrm{~cm}$ de altura por $1,8 \mathrm{~cm}$ de diâmetro. Os espacos vazios dentro dos tubos também foram preenchidos com folhas de alumínio, para năo variar a posiçáo das amostras durante a irradiaçäo ou mesmo no trânsito do "coelho" até ao núcleo do reator.

As amostras foram irradiadas com nêtrons térmicos no reator de pesquisa IAE-R1, IPEN - Săo Paulo. As amostras da primeira etapa foram irradiadas por um período aproximado de oito horas $(13 / 07 / 87)$, sendo submetidas a fluxo da ordem de $5.1012 \mathrm{n} . \mathrm{om}^{-2} . \mathrm{s}^{-1}$. As amostras de cana e de solos da segunda etapa foram irradiadas simultaneamente por um periodo de $7 \mathrm{~h}$ e $18 \mathrm{~min}$ $(08 / 07 / 87)$ e as da terceira, por $7 \mathrm{~h}$ e $27 \mathrm{~min}(07 / 10 / 87)$, ambas as séries com fluxo de nêtrons têrmicos da ordem de $1013 \mathrm{n} \cdot \mathrm{cm}^{-2} \cdot \mathrm{s}^{-1}$. 
3.5. Detecçấ

Fara a calibracáo do sistema detector na faixa de energia de 40 a $1600 \mathrm{keV}$, foram selecionados dois nuclideos emissores de raios gama de energias conhecidas, $137 \mathrm{Cs}(661,645 \mathrm{keV})$ e 60Co $(1332,501 \mathrm{keV})$. Apenas estes dois pontos foram utilizados, porque o amplificador usado mostrou-se, em ensaio preliminar, suficientemente linear. - posicionamento dos fotopicos de calibragáo na escala desejada foi efetuado pelo ajuste do fator de amplificaçăo, sendo a seguir coletado um espectro de cada padrăo, por periodo de tempo suficiente para produzir fotopicos bem definidos e resolvidos. Estabelecidas as regiōes de interesse, realizou-se a correspondência entre canal e energia através do programa interno do analisador multicanal, fornecendo-se os parâmetros exigidos.

Jma vez conhecidas as energias dos fotopicos dos espectros das diversas amostras, foi possivel a identificagáo dos radionuclideos correspondentes através de tabelas de energias dos catálogos de raios gama (HEATH, 1985; EKSTROM \& ANDERSSON, 1985; EKSTROM et alii, 1985).

Após um periodo de resfriamento de três dias, as capsulas de irradiaçăo foram retiradas do envoltório de folha de aluninio antes de se proceder à detecóa. 0 
aluminio comercial contém várias impurezas ativáveis, tendo sido constatada no material utilizado a presença de háfnio, ferro, cobalto e outros radionuclídeos. ATALLA \& REQUEJO (1982) relataram a presença de urânio em folhas de alumínio usadas para o mesmo objetivo.

Em seguida, as cápsulas foram colocadas no centro de frascos cilíndricos especiais de deteccăo $(3 \mathrm{~cm}$ de diâmetro por $4 \mathrm{~cm}$ de altura), com baixa radiação de fundo. Estes frascos foram centralizados sobre o detector de germânio pela utilização de um suporte de acrilico projetado para esta finalidade. Desta forma, foi possível manter inalterada a geometria de deteç̧o para todas as amostras, permanecendo constante a distância entre amostra e superficie do detector, de apenas $2 \mathrm{~mm}$, correspondente às espessuras das paredes do frasco e da cápsula de irradiaça.

Na primeira etapa, foram efetuadas seis séries de contagens por amostra, iniciando com um tempo de detecça de 30 min e alcançando até 240 min na laltima série. Na segunda etapa, foram realizadas quatro séries de contagens para cada amostra, a litima sendo três meses após a irradiaçáo. O tempo de deteç̧áo inicial foi de 30 e 60 min e o final de 60 e $120 \mathrm{~min}$, para solos e canas, respectivamente. Já na terceira etapa, apenas três sêries 
foram efetivadas, com o tempo de detecoko variando de acordo com a atividade das amostras, de 30 a 240 min.

A coleta de dados referentes às áreas e centróides dos fotopicos foi efetuada através do programa interno do analisador multicanal e, paralelamente, com arquivo de dados em discos, pelo programa desenvolvido em linguagem BASIC ( 8 bits) por NASCIMENTO $\mathrm{F}^{\circ}$ et alii (1988).

3.6. Análise química

Os teores de ferro das dez amostras de solo da segunda etapa foram determinados quimicamente por espectrometria de emissäo atômica com plasma induzido em argônio, empregando-se o sistema EIA-GSAM (GINE, 1986).

Para esta determinaçăo, $250 \mathrm{mg}$ de amostra de solo, em três repetiçöes, foram digeridos em bomba de teflon com $3 \mathrm{ml}$ de ácido nitrico concentrado. Após um periodo de repouso de duas horas, foram adicionados $2 \mathrm{ml}$ de ácido cloridrico concentrado e $3 \mathrm{ml}$ de ácido fluorfdrico, permanecendo no bloco de digestäo por duas horas e, em seguida, $3 \mathrm{ml}$ de ácido perclórico até a evaporaçäo, a $210^{\circ} \mathrm{C}$. O residuo foi retomado com $5 \mathrm{ml}$ de 
ácido cloridrico 1 if e o volume completado a $100 \mathrm{ml} c 0 m$ água deionizada.

Para se avaliar a exatidäo desta determinacäo, o mesmo procedimento foi seguido para amostra padräo de solo, "Soil 5", da Agência Internacional de Energia Atômica, com teor certificado de ferro.

No caso das amostras de cana, os teores de ferro foram avaliados por espectrometria de absorcão atômica nos solubilizados resultantes da digeståo nitroperclórica de $750 \mathrm{mg}$ do material finamente pulverizado (item 3.1), preparados em triplicata. Encontra-se detalhadamente descrita na literatura a análise de ferro em material vegetal, compreendendo a técnica utilizada no preparo das amostras e padröes (KRUG et alii, 1977) e o método de determinaçäo empregado (ZAGATTO et alii, 1981).

3.7 . Instrumentaça

- sistema de deteccăo de radiaya gama é composto pelo detector semicondutor coaxial de germânio niperpuro de alta resolucăo, de $65 \mathrm{~cm}^{3}$ (EG\&G ORTEC, modelo GEM-10195), envolto em cápsula de aluminio e circundado 
por blindagem de $5,5 \mathrm{~cm}$ de chumbo e $5,5 \mathrm{~cm}$ de ferro, com revestimento interno de cobre, módulo amplificador (ORTEC, modelo 472), módulo de alta tensăo ("bias supply", ORTEC modelo 459) e analisador de pulsos de 4096 canais (EG\&G ORTEC, modelo 7450 ).

Através da saida serial 2, 0 analisador multicanal foi ligado à interface serial RS-232 C de um microcomputador de 8 bits e a saída serial 1 conectada à impressora gráfica, obedecendo a comandos diretos do microprocessador interno do analisador multicanal.

3.8. Determinaça da eficiência do sistema detector

Para a determinacăo da eficiência do sistema detector de germânio no arranjo geométrico definido, foi empregado um conjunto de emissores gama calibrados, de fabricaça New England Nuclear, modelo NES-101-S, serie 230-035. Essas fontes puntuais, sob forma de pastilhas, foram colocadas diretamente sobre o suporte anteriormente especificado, com tempo de deteccăo variando de modo a permitir contagem acumuiada no fotopico, com valor minino previamente estabelecido de 2000 contagens e tempo morto inferior a $1 \%$. A geometria foi a mesma daquela usada no 
item 3.5, devido à similaridade construtiva e de dimensdes entre as cápsulas dos padróes e das amostras.

A contagem foi determinada através do cálculo da área na regiấo de interesse sob o fotopico, pelo método interno do analisador multicanal, e denominada I, ou seja, número total de eventos contados. As atividades das fontes na data de deteç㔯 (A) foram calculadas em desintegracöes por segundo (dps), a partir dos valores certificados de atividades $(A O)$ e das intensidades de emissăo de raios gama $(\theta)$.

A partir desses parametros, a eficiêncla $(\epsilon)$ para o fotopico foi calculada da seguinte forma:

$$
\epsilon=I / t_{d} \cdot A \cdot \theta
$$

lembrando que

$$
A=A_{0} \cdot e^{-\ln 2 \cdot t / T}
$$

sendo

I : número de eventos detectados

ta : tempo de detecs品

$\theta$ : intensidade de emissäo de raios gama

T : meia-vida física 
O erro relativo da eficiencia foi obtido pelo método de propagaça de erros (BRUNE et alii, 1984), com a equação:

$\left.\sigma \epsilon / \epsilon=\left[(1 / \sqrt{ })^{2}+(\sigma \theta / \theta)^{2}\right)+(\sigma A O / A O)^{2}+(\sigma I / T)^{2}\right]^{1 / 2 \ldots(4)}$

onde $\quad \sigma I=f I$ e $\sigma t d \approx 0$ săo obtidos experimentalmente e $\sigma \theta, \sigma A O$ e $\sigma \mathrm{T}$, fornecidos por tabelas (IAEA, 1978).

No intervalo de energia selecionado (40-1600 keV), foi traçada uma curva correlacionando o logaritmo da eficiência e a energia. Além disso, estabeleceu-se uma equaçăo para a faixa de energia compreendida entre 120 e $1400 \mathrm{keV}$.

3.9. Determinaçăo da atividade inicial

A atividade inicial de cada radionuclideo, ou seja, a atividade obtida ao término da irradiaçäo, foi estimada peia média das atividades corrigidas para os tempos de resfriamento considerados. Conforme já visto

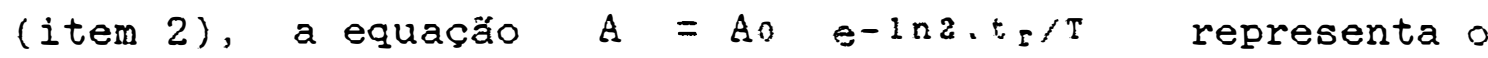
decaimento radioativo da atividade (A) em funcäo do tempo 
de resfriamento $(t r)$, sendo. Ao a atividade no final da irradiaçăo $\left(t_{r}=0\right)$ e $T$ a meia-vida do radionuclideo.

A atividade atual (A), em desintegraçóes por segundo, foi calculada a partir da taxa líquida de contagem, em contagens por segundo, da eficiência do sistema detector para a energia considerada $(\epsilon)$ e da intensidade de emissăo do raio gama $(\theta)$, conforme a equaçăo 3 , descrita para o cálculo da eficiência.

A taxa liquida de contagem resultou da divisăo da área delimitada sob o fotopico (I) pelo tempo real de contagem (ta). Os parâmetros referentes à eficiência foram obtidos pela curva preliminarmente estabelecida e os valores de intensidade de emissăo de raios gama retirados das tabelas mencionadas (item 3.5 ).

3.10. Determinaçăo do fluxo de nêutrons

Dma vez que $\circ$ fluxo de nêutrons năo foi monitorado e que comparadores năo foram irradiados juntamente às amostras, sua obtença foi indiretamente realizada pelo teor de ferro das amostras obtido via química, através do método de padronizaçăo interna (LELIAERT et al1i, 1958). 
0 elemento ferro foi escolhido pelo fato de estar normalmente presente nos solos e por ser determinado quimicamente com alta precisăo e exatidăo. Desse modo, através da solubilização das amostras de solo conforme procedimento anteriormente descrito (item 3.6), o ferro foi determinado por espectrometria de emissăo atômica com plasma induzido em argônio.

A partir das taxas liquidas de contagem dos raios gama principais do $59 \mathrm{Ee}, 1099,22$ e $1291,56 \mathrm{keV}$. medidas nos vários tempos de resfriamento, da eficiencia do sistema nas energias consideradas e da intensidade de emissão dos raios gama, foram calculadas as atividades atuais e iniciais do radionuclideo para cada amostra, em desintegraçós por segundo.

Conhecendo-se a concentraçá de ferro das amostras e, conseqüentemente, as massas ativadas do elemento, os fluxos foram calculados através da equaça 5, originada da equaçăo 1 (item 2):

$\Phi=A_{0} \cdot M / 6,02 \cdot 10^{-3} \cdot \sigma \cdot \theta \cdot m \cdot\left(1-e^{\left.-1 n 2 t_{i} / T\right) \ldots(5)}\right.$

onde

$\Phi=$ fluxo de nêtrons (n.cm-2.s $\left.s^{-1}\right)$ 


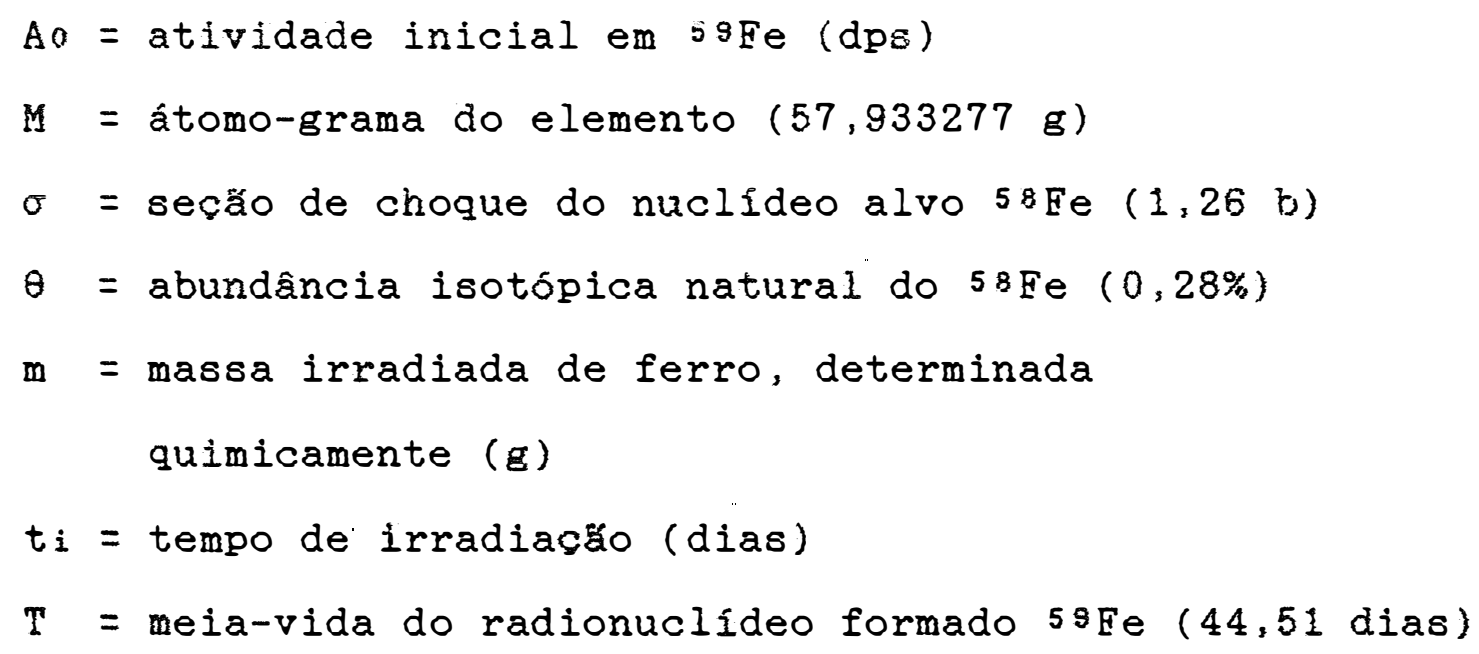

Segundo esse procedimento, na segunda etapa, o fluxo de nêtrons que cada amostra recebeu teve sua intensidade estimada pela média de oito valores encontrados de fluxos, correspondentes aos dois fotopicos selecionados em quatro tempos de resfriamento.

Para a terceira etapa, o fluxo de nêtrons de cada amostra foi estimado pela média de seis valores de fluxos, relativamente aos dois fotopicos do $59 \mathrm{Fe}$, em três tempos de resfriamento. 
4. RESULTADOS E DISCUSSAO

4.1. Calibracăo do sistema detector

As diferencas entre os valores de energia assinalados pelas centróides calculadas pelo programa do analisador multicanal e aqueles constantes das tabelas consultadas variaram no máximo $0,5 \mathrm{keV}$, para as energias abaixo de $100 \mathrm{keV}$.

Pequenos desvios da linearidade foram observados devidos, principalmente, ao equipamento de amplificaça, obtendo-se exatidgo de $0,2 \mathrm{keV}$ para os fotopicos mais importantes do espectro de raios gama, demonstrado pelo teste de linearidade efetuado com uma amostra irradiada de solo. Tal exatidäo foi, em geral, suficiente para permitir identificacăo direta de um 
nuclídeo, sem demais conhesimentos concernentes às propriedades de decaimento. Dessa maneira, foi possivel identificar confiavelmente os radionuclideos, ainda mais que grande número deles apresenta dois ou mais fotopicos. Este fato serviu como confirmaça da presenca de um dado radionuclídeo, pela determinaçáo das taxas liquidas de contagem relativas dos fotopicos, uma vez identificado o fotopico principal.

o conhecimento e acompanhamento das meiasvidas foram de importancia nos casos em que o radionuclideo apresentava somente um fotopico bem definido ou, entáo, quando havia sobreposicáo de fotopicos de energias muito próximas de radionuclídeos distintos.

\subsection{Eficiência de detecça}

A eficiencia de deteçăo de um dado fotopico $\ell$ funça da eficiência intrínseca do detector, a qual depende da energia do raio gama e da geometria entre fonte e detector, e da razáo fotopico/total, que $e$ a razáo da area medida sob o fotopico pela area toval do espectro. Esforços têm sido feitos para calcular as eficiências de deteçáo dos fotopicos de detectores de germanio, mas 
ainda é preferível medi-las experimentalmente (BRUNE et alii, 1984).

A determinaçäo da curva de eficiencia relativa foi de particular importancia, sua exatidäo influenciando diretamente $\circ$ resultado final. Devido a dificuldades associadas ao cálculo teórico da eficiência de um detector, procedimentos experimentais săo normalmente adotados e, nesse caso, utilizou-se a prática mais comum, a dos emissores gama calibrados. Entretanto, deve-se considerar que a exatidăo das medidas é limitada à exatidäo com a qual a atividade das fontes foi obtida e de erros inerentes às demais medidas fisicas empregadas.

Neste trabalho, as taxas de contagem dos raios gama do $241 \mathrm{Am}, 109 \mathrm{Cd}, 57 \mathrm{Co}, 133 \mathrm{Ba}, 137 \mathrm{Cs}, 54 \mathrm{Mn}$ e $60 \mathrm{Co}$ foram medidas com o propósito de se traçar a curva de eficiencia relativa. A série de mediços foi repetida tres vezes. A taxa de desintegraçäo para as fontes padröes foi corrigida pelas meias-vidas. Na Tabela 2 , encontram-se as energias e respectivas eficiencias, obtidas a partir dos valores certificados de atividade e das taxas liquidas de contagem, bem como das intensidades de emissăo dos raios gama selecionados. 
Tabela 3. Valores de eficiência $(\epsilon \pm \sigma \epsilon$ ) para o siatema detector, calculados para as energias dos radionuclídeos usados como padröes, segundo equaçöes (3) e (4).

Nuclídeo

Energia

$(\mathrm{keV})$
Eficiência

(\%)
$133 \mathrm{Ba}$

$241 \mathrm{Am}$

$133 \mathrm{Ba}$

$109 \mathrm{Cd}$

$57 \mathrm{Co}$

$57 \mathrm{Co}$

$133 \mathrm{Ba}$

$133 \mathrm{Ba}$

$133 \mathrm{Ba}$

$133 \mathrm{Ba}$

$233 \mathrm{Ba}$

$137 \mathrm{Cs}$

$54 \mathrm{Mn}$

soco

$B O \mathrm{CO}$
$53,155 \pm 0,016$

$59,537 \pm 0,001$

$80,997 \pm 0,021$

$88,032 \pm 0,080$

$122,063 \pm 0,003$

$136,476 \pm 0,003$

$160,605 \pm 0,010$

$223,250 \pm 0,010$

$276,397 \pm 0,012$

$302,851 \pm 0,015$

$356,005 \pm 0,017$

$661,645 \pm 0,009$

$834,827 \pm 0,021$

$1173,238 \pm 0,004$

$1332,501 \pm 0,005$
$2,81 \pm 0,066$

$$
4,41 \pm 0,017
$$

$9,53 \pm 0,054$

$11,51 \pm 0,131$

$15,75 \pm 0,117$

$15,62 \pm 0,287$

$13,42 \pm 0,275$

$6,28 \pm 0,209$

$5,81 \pm 0,061$

$5,45 \pm 0,041$

$4,66 \pm 0,025$

$2,38 \div 0,021$

$1,95 \pm 0,060$

$1,30 \pm 0,011$

$1,10 \pm 0,010$ 
Para o cálculo da eficiência na regiăo de maior concentraça de fotopicos, foi preferivel estabelecer, pelo ajuste dos quadrados mínimos, uma equacăo que expressa a eficiência como funcäo da energia do raio gama, de modo que uma estimativa dos erros pode ser obtida (Tabela 3 ): O erro relativo da eficiência foi calculado conforme o descrito no item 3.8 , equara 4 .

Para energias compreendidas entre 120 e 1400 keV foram usados os valores obtidos pela equaça de regressäo linear $(r=0,9987)$ :

$$
\text { In } \in(\%)=7,694-1,051 \text { In } E(\mathrm{keV})
$$

4.3. Fluxo de nêtrons

Os erros introduzidos no processo de irradiaçăo resultam de múltiplos fatores como reacöes nucleares interferentes, nă homogeneidade do fluxo, efeitos de ressonância e sombreamento, ocasionando atenuaçăo do fluxo de nêtrons (ADAM \& DAMS, 1975).

Quando metodos comparadores săo utilizados, a fonte principal de erro é devida ao fato de que amostra e referencia nao ga expostas do mesmo fluxo de nextrone, 
por variaçóes ocorridas em funçáa do tempo (recessidade de irradiaçăo simultanea de amostra e padrắ), da posiç્áo de irradiacăo (por esta razăo, amostra e padrắo devem ser irradiados juntos no mesmo "coelho") e da profundidade (atenuacăo diferenciada do fluxo de nêtrons pelas próprias amostras e padröes, tornando $\circ$ interior da amostra ou do padrăo menos ativo que a parte exterior). Como ambos, amostra e padrão, podem estar separados por alguns centímetros dentro da cápsula de irradiaçăo, erros consideráveis săo possives, uma vez que gradientes da ordem de $10 \%$ por centímetro foram relatados para irradiacöes efetuadas em determinadas posicöes de reatores moderados à água (De SOETE et alii, 1972).

Estas restricőes podem ser grandemente reduzidas pelo uso de um padrăo interno. O metodo $E$ apropriado, requerendo como condiçăo única a presenca de um segundo elemento na amostra que possa ser ativado e medido independentemente do elemento a ser determinado e que origine uma atividade medida com boa exatidåo (LELIAERT et alii, 1958; HOSTE et alii, 1961).

Além dos diversos elementos comumente utilizados como monitores de fluxos (cobalto, ouro, prata, zircônio), o emprego de fios de ferro tem sido recomendado em análise de amostras de solo, para irradiacóes de longa 
duraça com îêtrons térmicos (KOONS \& HELMKE, 1978; SALMON \& CASE, 1986).

A escolna do elemento químico ferro como padră interno para a determinaça do fluxo de nêtrons térmicos relativo a cada amostra foi devida aos fatores considerados a seguir:

- ser um elemento de importância na constituicäo dos solos, em concentracóes na ordem de porcentagem. No presente trabalho, os teores de ferro de dez diferentes solos variaram de 0,85 a $18,49 \%$ (Tabela 4);

- apresentar segso de choque favorável para nêtrons térmicos, que associada à alta concentraçáo do elemento na amostra, resulte em taxas líquidas de contagem com valores suficientes para minimizar os erros estatísticos de contagem;

- estar homogeneamente distribuido na matriz do solo. Neste particular, deve-se levar em conta que testes de avaliacáo da homogeneidade de padröes certificados, tais como o "Soil-5", säo baseados na deteruinacäo dos teores de alguns elementos químicos ( $\mathrm{Fe}, \mathrm{Cs}, \mathrm{Co}$ ) através de análise por ativaçáo neutrônica instrumental (IAEA, 1978); 
Tabela 4. Resultados dos teores de ferro das amostras de solo e de cana da segunda etapa.

\begin{tabular}{ccc}
\hline Amostra & Solo & Cana \\
& Fe $\%)$ & Fe $(\mu g \cdot g-1)$ \\
\hline 1 & $2,340 \pm 0,042$ & 50 \\
2 & $0,887 \pm 0,010$ & 45 \\
3 & $4,834 \pm 0,069$ & 25 \\
4 & $2,709 \pm 0,039$ & 20 \\
5 & $0,850 \pm 0,014$ & 33 \\
6 & $18,487 \pm 0,365$ & 24 \\
7 & $5,629 \pm 0,077$ & 48 \\
8 & $1,794 \pm 0,036$ & 27 \\
9 & $15,401 \pm 0,253$ & 23 \\
10 & $3,920 \pm 0,079$ & 23 \\
\hline
\end{tabular}


- apresentar pelo menos dois raios gama $(1099,22$ e 1291,95 keV) situados além da regiăo de baixa energia, que sofre mascaramento por radiaçöes intensas e de altas energias;

- o radioisbtopo resultante da reacăo $58 \mathrm{Fe}(\mathrm{n}, \gamma) 59 \mathrm{Fe}$ apresenta constantes físicas favoráveis, como meia-vida de 44,51 dias, compativel com o experimento.

Os teores de ferro total das amostras de solo selecionadas para o segundo experimento, determinados por espectrometria de emissăo atômica com plasma induzido em argônio (item 3.6), situaram-se em uma faixa analitica abrangente, de 0,5 a $20 \%$ (Tabela 4). Para $\circ$ padrăo de referência certificado "Soil-5" (IAEA, 1978), obteve-se um teor de ferro de $4,57 \pm 0,09 \%$, média de três replicatas, em concordância com $\circ$ valor recomendado de $4,45 \pm 0,19 \%$. Em decorrência disso, os resultados de concentraçăo de ferro podem ser considerados corretos. A precisầ do método de determinaçăo foi avaliada (GINE, 1986), sendo seu desvio padräo relativo menor que $2 \%$.

Com os oito valores de taxas liquidas de contagem obtidos por amostra, correspondentes aos fotopicos de 1099,22 e $1291,56 \mathrm{keV}$ nas quatro séries de deteccăo, das eficiências do sistema detector (conforme item 3.8) e das intensidades de emissáo dos raios gama, 
foram calculadas as atividades iniciais em $59 \mathrm{Fe}$ para as dez amostras de solo. A partir dessas atividades, expressas em becquerel, das constantes físicas do nuclídeo alvo $58 \mathrm{Fe}$ (seçăo de choque, abundancia isotopica natural, átomo-grama), do tempo de irradiaça e das massas irradiadas de ferro avaliadas quimicamente, foram estimados os fluxos de nêtrons que cada amostra recebeu (Tabela 5), através da equaçáo 5 (item 3.10). Observa-se que $\circ$ fluxo variou de 9,7 a $11,5.1012$ nêtrons.cm-2.s.-1, refletindo a ocorrência de gradientes de fluxos entre amostras, da ordem de $30 \%$. Esta variacăo pode ser justificada pelos diferentes posicionamentos das cápsulas com as amostras durante a irradiaçáo, pois as mesmas foran arranjadas em três "coelhos" distintos.

Deve ser enfatizado que as médias dos valores de fluxos obtidos para cada fotopico do $59 \mathrm{Fe}$ năo mostraram diferenças significativas entre si. Apesar de haver sido verificada a presença de tântalo nas amostras de solos, observada pelos vários fotopicos do $182 \mathrm{Ta}$ nos espectros, 0 de $1289,13 \mathrm{keV}$ năo interferiu na deteccáo do fotopico de $1291,56 \mathrm{keV}$ do $59 \mathrm{Fe}$.

No cálculo do fluxo de nêtrons para os pontos da curva de adiçăo de solo da terceira etapa, foram 
Tabela 5. Valores calculados dos fluxos de nêtrons (1012 n.cm.s-1) através dos fotopicos do $59 \mathrm{Fe}$, para as dez amostras de solo da segunda etapa, conforme item 3.10 .

\begin{tabular}{|c|c|c|c|c|}
\hline \multirow[t]{2}{*}{ Amostra } & \multicolumn{3}{|c|}{ Eotopico } & \multirow{2}{*}{$\begin{array}{l}\text { Média } \\
\text { Geral }\end{array}$} \\
\hline & 1099 & $\mathrm{keV}$ & $1291 \mathrm{keV}$ & \\
\hline 1 & $9,5 \pm$ & 0,13 & $9,8 \pm 0,20$ & $9,7 \pm 0,18$ \\
\hline 2 & $10,2 \pm$ & 0,07 & $10,3 \pm 0,10$ & $10,3 \pm 0,10$ \\
\hline 3 & $10,4 \pm$ & 0,17 & $10,5 \pm 0,14$ & $10,4 \pm 0,15$ \\
\hline 4 & $11,3 \pm$ & 0,17 & $11,7 \pm 0,25$ & $11,5 \pm 0,27$ \\
\hline 5 & $8,4 \pm$ & 0,25 & $8,5 \pm 0,43$ & $8,5 \pm 0,18$ \\
\hline 6 & $10,2 \pm$ & 0,25 & $10,4 \pm 0,51$ & $10,3 \pm 0,40$ \\
\hline 7 & $9,6 \pm$ & 0,11 & $9,7 \pm 0,17$ & $9,6 \pm 0,16$ \\
\hline 8 & $10,5 \pm$ & 0,14 & $10,6 \pm 0,15$ & $10,5 \pm 0,14$ \\
\hline 9 & $10,6 \pm$ & 0,21 & $10,7 \pm 0,20$ & $10,7 \pm 0,19$ \\
\hline 10 & $10,1 \pm$ & 0,10 & $10,2 \pm 0,11$ & $10,2 \pm 0,11$ \\
\hline
\end{tabular}


considerados os teores de ferro dos componentes da mistura, ou seja, solo e cana finamente pulverizados, preparados como descrito em 3.1 e 3.2 . Desse modo, os valores das massas de ferro resultaram da média ponderada das quantidades de solo e de cana relacionadas às respectivas concentraços de ferro, correspondentes a 8500 e $33 \mathrm{\mu g} \cdot \mathrm{g}^{-1}$ (Tabela 6).

4.4. Atividades e massas

Uma vez obtida a eficiência do sistema detector em condiçoses identicas àquelas estabelecidas para análise das amostras, foram calculadas as taxas de desintegraçáo ou atividades dos radionuclideos formados durante a ativaçáo, para os tempos de resfriamento adotados em cada etapa. Com os valores de atividade inicial corrigidos para o término da irradiaçăo, do fluxo de nêtrons especifico para cada amostra, do tempo de irradiaçáo e demais parâmetros da equaçáo 1 , retirados da literatura, foi possivel estimar as massas irradiadas de cada elemento ativado na matriz do solo. 
Tabela 6. Valores calculados dos fluxos de nêtrons (1012 n.cm.s-1) recebidos pelas amostras da curva de adica de solo da terceira etapa, com as respectivas massas irradiadas de ferro ( $\mu \mathrm{g})$.

\begin{tabular}{ccccc}
\hline Amostra & Solo $\%$ & \multicolumn{2}{c}{ Massa de Ferro } & Eluxo \\
& MS* & Solo & Cana & médio \\
\hline 1 & cana & 0 & 3,3 & 5,7 \\
2 & 0,5 & 4,25 & 3,28 & 5,6 \\
3 & 1,0 & 8,5 & 3,27 & 5,5 \\
4 & 1,5 & 12,5 & 3,25 & 6,4 \\
5 & 2,0 & 17,0 & 3,23 & 5,5 \\
6 & 3,0 & 25,5 & 3,20 & 5,5 \\
7 & 4,0 & 34,0 & 3,17 & 7,3 \\
8 & 6,0 & 51,0 & 3,10 & 8,4 \\
9 & 8,0 & 68,0 & 3,04 & 5,7 \\
10 & solo & 850 & 0 & 7,6 \\
\hline
\end{tabular}

* matéria seca da cana com o solo 
4.4.1. Primeira etapa

Tendo sido encontrado um valor de $71,87 \%$ para umidade \% cana, os pontos da curva de adiçăo de solo da primeira etapa, anteriormente expressos como $0,0,49,0,97$ e 1,87 de solo \% matéria úmida, correspondem a $0,1,75$, 3,43 e 6,64 de solo \% matéria seca. Tanto estas amostras como as três de solos irradiadas simultaneamente foram detectadas em seis tempos de resfriamento, correspondendo a aproximadamente $4,11,18,27,90$ e 103 dias da data de irradiaça. Para os cálculos foram considerados os tempos corretos em segundos.

Os espectros de energias gama obtidos nas primeiras medidas apresentavam-se bastante complexos, com existência de muitos fotopicos, alguns sobrepostos, o que dificultava sobremaneira a identificaçăo e quantificaçăo dos mesmos. Entretanto, mediante comprovaçäo do decaimento pelo acompanhamento das meias-vidas, foi possível uma avaliaçáo qualitativa segura dos radionuclideos formados. Observou-se a presença de alguns elementos da série dos lantanídeos tais como o lantânio (140 La), európio (152Eu), cério (141Ce), samário (153 $\mathrm{sm}$ ) e itérbio (169Yb) e outros da série dos actinideos como o tório (233Pa) e urânio $(239 \mathrm{~Np})$. Desses elementos, apenas o lantânio e o európio apresentaram atividade suficiente para serem detectados 
com precisåo compativel aos parâmetros adotados no experimento. Dos elementos maiores, situados na faixa de porcentagem, foi detectado apenas o ferro (59Ee e $54 \mathrm{Mn}$ ) e dentre aqueles normalmente caracterizados como elementos menores a traços, o escândio (46SC), o háfnio (181Hf) e o cobalto ( $60 \mathrm{Co})$.

Pela análise dos vários espectros obtidos para as amostras, percebeu-se a predominância do fotopico de $1368,6 \mathrm{keV}$ do $24 \mathrm{Na}$ nas primeiras séries de medidas, além da presença de outros como os de 312,60 e $1524,6 \mathrm{keV}$ do $42 \mathrm{~K}$ e mais uma dezena de fotopicos do $82 \mathrm{Br}$, todos com alta atividade. Somando-se a esses os vários fotopicos do $140 \mathrm{La}$, distribuidos em praticamente toda a abrangência de energia do espectro, desde 109,6 a $1596,17 \mathrm{keV}$, os de 69,674 e $103,180 \mathrm{KeV}$ do $153 \mathrm{Sm}$ e diversos do $187 \mathrm{~W}, 72 \mathrm{Ga}$, 239Np, pode-se avaliar a dificuldade de se proceder à identificaçäo dos radionuclideos presentes na anostra.

Ima análise comparativa das três amostras irradiadas de solos, diferenciadas entre si pela classe textural, evidenciou acentuada variabilidade entre as atividades induzidas de alguns elementos. Dessa maneira, para uma escolha efetiva dos meihores traçadores de solo, na segunda etapa, foram coletadas amostras representativas dos solos canavieiros do Estado de Szo Palo. 
Para o elemento ferro, os dados resultaram da média de doze valores de atividades corrigidas para $\circ$ término da irradiaçăo, correspondendo aos dois fotopicos de maior intensidade do 59Ee, 1099,22 e 1291,56 keV, nos seis tempos de resfriamento. O fotopico de $142,65 \mathrm{keV}$ năo foi utilizado devido à interferência verificada do fotopico de $145,4 \mathrm{keV}$ do $141 \mathrm{Ce}$.

Da mesma forma que para o ferro, as atividades de escandio foram obtidas da média de doze valores, relativos aos fotopicos de 889,25 e $1120,51 \mathrm{keV}$ do $46 \mathrm{Sc}$.

Dentre os fotopicos do $181 \mathrm{Hf}$ foi escollido unicamente $\circ$ de $482,00 \mathrm{keV}$, apesar da proximidade do fotopico de $487,01 \mathrm{keV}$ do $140 \mathrm{La}$, presente na primeira deteçăo. Embora o fotopico de $132,94 \mathrm{keV}$ seja o mais facilmente detectado, ao se considerar a eficiencia do sistema detector $(\epsilon=15,8)$ e a intensidade de emissăo do raio gama $(\theta=36 \%)$, ele năo foi utilizado devido à interferência sofrida pelo posicionamento na faixa de baixa energia do espectro. O fotopico de $345,83 \mathrm{keV}$ tem energia muito próxima à do $344,27 \mathrm{keV}$ do $152 \mathrm{Eu}$, năo sendo recomendável a sua utilizaçåo.

Devido à meia-vida curta do $140 \mathrm{La}(40,28 \mathrm{~h})$, só foi possivel coletar dados na primeira série de 
deteçăo. Foram escolhidos os fotopicos de $487,01,815,77$ e $1596,17 \mathrm{keV}$, resultando em três pontos para a obtençáo do valor da atividade de cada amostra.

Embora $\bigcirc \quad 152 \mathrm{Eu}$ apresente vários fotopicos de considerável intensidade, apenas os de 121,78 e $344,27 \mathrm{keV}$ apareceram em condiçós de serem aproveitados. Entretanto, este segundo näo foi utilizado devido à interferência causada pelo fotopico de $345,83 \mathrm{keV}$ do $181 \mathrm{Hf}$ por haver sobreposicáo parcial de ambos. Mesmo para o fotopico de $121,78 \mathrm{keV}$, observou-se interferencia acentuada nas taxas liquidas de contagem da primeira série, näo tendo sido inclusive utilizadas no cálculo da média. Este fato evidenciou a presença de algum radionuclideo emissor gama de mesma energia, porém de meia-vida curta, possivelmente - próprio $152 \mathrm{Eu}$ metaestável, com decaimento por captura de elétron e meia-vida de $9,32 \mathrm{~h}$.

A atividade em BoCo de cada amostra resultou da média de doze valores, correspondentes aos fotopicos de 1173,21 e $1332,47 \mathrm{keV}$.

Os valores encontrados para os elementos analisados nas quatro amostras encontram-se na Tabela 7. 
Tabela 7. Teores obtidos dos elementos $\left(\mu \mathrm{g} \cdot \mathrm{g}^{-1}\right)$ nas amostras da primeira etapa.

\begin{tabular}{|c|c|c|c|c|c|}
\hline Elemento & $\begin{array}{l}\text { Solo \% } \\
\text { cana }\end{array}$ & $\begin{array}{l}\text { Número } \\
\text { dados }\end{array}$ & $\begin{array}{l}\text { Média } \\
\left(\mu \mathrm{g} \cdot \mathrm{g}^{-1}\right)\end{array}$ & $\begin{array}{l}\text { Desvio } \\
\text { padráo }\end{array}$ & $\begin{array}{l}\mathrm{CV} \\
(\%)\end{array}$ \\
\hline $\mathrm{Hf}$ & $\begin{array}{l}0 \\
0,5 \\
1 \\
2\end{array}$ & $\begin{array}{l}5 \\
6 \\
5 \\
6\end{array}$ & $\begin{array}{l}0,125 \\
0,184 \\
0,175 \\
0,240\end{array}$ & $\begin{array}{l}0,008 \\
0,003 \\
0,005 \\
0,012\end{array}$ & $\begin{array}{l}6,8 \\
1,8 \\
3,0 \\
5,0\end{array}$ \\
\hline Sc & $\begin{array}{l}0 \\
0,5 \\
1 \\
2\end{array}$ & $\begin{array}{l}10 \\
12 \\
12 \\
12\end{array}$ & $\begin{array}{l}0,041 \\
0,222 \\
0,352 \\
0,656\end{array}$ & $\begin{array}{l}0,003 \\
0,007 \\
0,008 \\
0,024\end{array}$ & $\begin{array}{l}6,8 \\
3,2 \\
2,3 \\
3,6\end{array}$ \\
\hline $\begin{array}{l}\mathrm{Fe} \\
(\%)\end{array}$ & $\begin{array}{l}0 \\
0,5 \\
1 \\
2\end{array}$ & $\begin{array}{l}10 \\
12 \\
12 \\
12\end{array}$ & $\begin{array}{l}36,64 \\
51,97 \\
61,51 \\
92,73\end{array}$ & $\begin{array}{l}1,58 \\
1,30 \\
1,47 \\
2,70\end{array}$ & $\begin{array}{l}4,3 \\
2,5 \\
2,4 \\
2,9\end{array}$ \\
\hline Co & $\begin{array}{l}0 \\
0,5 \\
1 \\
2\end{array}$ & $\begin{array}{l}10 \\
12 \\
12 \\
12\end{array}$ & $\begin{array}{l}3,968 \\
4,013 \\
4,413 \\
5,420\end{array}$ & $\begin{array}{l}0,145 \\
0,180 \\
0,240 \\
0,312\end{array}$ & $\begin{array}{l}3,7 \\
4,5 \\
5,4 \\
5,7\end{array}$ \\
\hline La & $\begin{array}{l}0 \\
0,5 \\
1 \\
2\end{array}$ & $\begin{array}{l}3 \\
3 \\
3 \\
3\end{array}$ & $\begin{array}{l}0,439 \\
0,593 \\
0,628 \\
0,104\end{array}$ & $\begin{array}{l}0,014 \\
0,193 \\
0,041 \\
0,014\end{array}$ & $\begin{array}{l}3,2 \\
3,2 \\
6,5 \\
1,3\end{array}$ \\
\hline Eu & $\begin{array}{l}0 \\
0,5 \\
1 \\
2\end{array}$ & $\begin{array}{l}3 \\
4 \\
5 \\
4\end{array}$ & $\begin{array}{l}0,005 \\
0,007 \\
0,008 \\
0,016\end{array}$ & $\begin{array}{l}0,001 \\
0,001 \\
0,001 \\
0,002\end{array}$ & $\begin{array}{r}13,0 \\
8,7 \\
16,3 \\
12,7\end{array}$ \\
\hline
\end{tabular}


Estabelecendo-se comparaçäo entre teores de solo adicionados à cana (solo \% matéria seca) e atividades calculadas, foram obtidas as regressóes lineares para cada elemento (Tabela 8). o escândio e 0 ferro foram os elementos que apresentaram melhor correlaça entre os pares de dados e, conseqüentemente, menores coeficientes de variaçåo entre teores esperados e caloulados.

Independentemente do elemento em questäo, o valor recuperado para a amostra com adicao de $3,43 \%$ de solo apresentou-se sistematicamente menor, $\circ$ que pode sustentar duas alternativas. A primeira seria a de que a massa de solo adicionada estivesse situada em um valor abaixo do considerado, possivelmente devido à perda de solo por falta de aderência e retençáo das particulas à superficie das fibras de cana desintegrada. A deficiencia no preparo da amostra pode ter sido ocasionada pela deposicăo preferencial das particulas densas do solo durante o processamento da amostra, nas fases de secagem e moagem. Uma segunda hipótese recai na năo uniformidade do fluxo de nêtrons recebido pelas amostras, o qual, para efeito de cálculos, foi considerado constante nessa etapa $\left(5.1012 \mathrm{n} \cdot \mathrm{cm}^{-2} \cdot \mathrm{s}^{-1}\right)$. Dessa maneira, variaçbes ocorridas podem ter induzido atividades diferenciadas e, então, os resultados näo podem ser simplesmente comparados entre si, sem que se proceda a correcáo desses valores. 
Tabela 8. Análise da regressäo entre o solo adicionado à cana e os teores dos elementos analisados nas amostras da primeira etapa.

\begin{tabular}{|c|c|c|c|c|}
\hline Elemento & $\begin{array}{l}\text { Número } \\
\text { dados }\end{array}$ & $\begin{array}{c}\text { Coeficiente } \\
r\end{array}$ & $\begin{array}{c}\text { Teste } \\
t\end{array}$ & $\begin{array}{c}\text { Erro } \\
\text { (solo\%MS*) }\end{array}$ \\
\hline Háfnio & 22 & 0,9239 & $10,79 * *$ & 0,99 \\
\hline Escândio & 46 & 0,9974 & $91,60 * *$ & 0,18 \\
\hline Eerro & 46 & 0,9918 & $51,36 * *$ & 0,32 \\
\hline Cobalto & 46 & 0,9022 & $13,87 * *$ & 1,07 \\
\hline Lantânio & 12 & 0,9679 & $12,19 * *$ & 0,67 \\
\hline Europio & 16 & 0,9317 & $9,60 * *$ & 0,90 \\
\hline
\end{tabular}

* Matéria seca da cana com solo

** Significativo ao nivel de $0,1 \%$ de probabilidade 


\subsubsection{Segunda etapa}

Para aqueles radionuclideos que apresentam mais de um fotopico em seu esquema de decaimento e que tiveram condiçes de serem detectados, os valores finais de massa apresentados (Tabela 9 ) săo médias dos valores parciais encontrados, nas séries de corridas efetuadas.

Dessa maneira, pela utilizaçăo dos dois fotopicos do $46 \mathrm{Sc}$, os valores finais dos teores de escândio dos solos resultaram da média de oito medidas. Mesmo tendo sido verificada a presenca de $182 \mathrm{Ta}$, com um fotopico de proeminềncia em $1121,27 \mathrm{keV}$, o segundo em probabilidade de emissăo de raios gama $(\theta=35,0 \%)$ em seu esquema de decaimento, năo houve diferença significativa entre os teores encontrados, relativamente aos fotopicos de 889,25 e 1120,51 keV. Assim sendo, pode-se considerar insignificante a interferência do tântalo sobre a determinaçăo do escândio, com referência ao segundo fotopico do $46 \mathrm{SC}$.

- radionuclídeo formado $140 \mathrm{La}$ só pode ser medido nas duas primeiras séries de deteçáo e, mesmo assim, com taxas liquidas de contagem bastante reduzidas na segunda série, o que prejudicou razoavelmente a estatistica de contagem. A média foi resultante de seis 
Tabela 9. Teores dos elementos encontrados nas amostras de solos ( $\left.\mu g \cdot g^{-1}\right)$ da segunda etapa.

\begin{tabular}{cccc}
\hline Amostra & Sc & Hf & Eu \\
\hline 1 & $9,25 \pm 0,06$ & $10,41 \pm 0,26$ & $0,36 \pm 0,04$ \\
2 & $4,44 \pm 0,03$ & $11,30 \pm 0,26$ & $0,18 \pm 0,02$ \\
3 & $17,34 \pm 0,16$ & $11,12 \pm 0,06$ & $0,26 \pm 0,04$ \\
4 & $9,99 \pm 0,10$ & $8,50 \pm 0,05$ & $0,15 \pm 0,02$ \\
5 & $4,23 \pm 0,05$ & $11,09 \pm 0,03$ & $0,19 \pm 0,02$ \\
6 & $65,45 \pm 1,50$ & $9,33 \pm 0,27$ & $0,95 \pm 0,09$ \\
7 & $28,89 \pm 0,48$ & $21,62 \pm 0,54$ & $0,27 \pm 0,05$ \\
8 & $8,42 \pm 0,07$ & $8,89 \pm 0,24$ & $0,20 \pm 0,03$ \\
9 & $54,06 \pm 1,08$ & $10,05 \pm 0,21$ & $0,56 \pm 0,08$ \\
& $16,04 \pm 0,18$ & $13,95 \pm 0,40$ & $0,25 \pm 0,03$
\end{tabular}


Tabela 9. Teores dos elementos encontrados nas amostras de solos ( $\mu g . g-1)$ da segunda etapa.

$\begin{array}{lllll}\text { Amostra La } & \text { Lo } & \mathrm{Cs} & \mathrm{Sm}\end{array}$

\begin{tabular}{lllllll}
1 & $22,13 \pm 1,00$ & $10,90 \pm 0,26$ & $2,28 \pm 0,19$ & 4,35 \\
2 & $11,90 \pm 0,23$ & $0,89 \pm 0,06$ & $0,67 \pm 0,08$ & 2,41 \\
3 & $13,40 \pm 0,49$ & $6,01 \pm 0,22$ & $8,14 \pm 0,44$ & 2,76 \\
4 & $8,36 \pm 0,70$ & $1,19 \pm 0,05$ & $1,04 \pm 0,11$ & 1,58 \\
5 & $9,46 \pm 0,27$ & $1,62 \pm 0,10$ & $1,51 \pm 0,12$ & 1,95 \\
6 & $18,69 \pm 0,91$ & $31,18 \pm 0,92$ & $0,70 \pm 0,13$ & 6,14 \\
7 & $9,31 \pm 0,57$ & $9,42 \pm 0,21$ & $4,06 \pm 0,41$ & 2,68 \\
8 & $7,42 \pm 0,41$ & $1,81 \pm 0,13$ & $1,10 \pm 0,13$ & 1,78 \\
9 & $15,11 \pm 0,91$ & $57,86 \pm 2,05$ & $0,54 \pm 0,11$ & 3,71 \\
10 & $17,16 \pm 0,67$ & $3,54 \pm 0,11$ & $5,85 \pm 0,44$ & 2,30 \\
\hline
\end{tabular}


vaiores, correspondendo aos fotopicos de $328,76,487,01$ e $1596,17 \mathrm{keV}$ em dois tempos de resfriamento.

O fotopico de $121,78 \mathrm{keV}$ do $152 \mathrm{Eu}$ é o que tem maior probabilidade de ocorrência de eventos $(\theta=28 \%)$ e de registro deles $(\epsilon=15,75 \%)$. Entretanto, apesar destas características favoráveis intrínsecas, sua quantificação fica prejudicada devido à componente Compton dos raios gama de alta energia de outros nuclídeos presentes. Com o decorrer do tempo, a interferência foi sendo minimizada e os valores das taxas liquidas de contagem foram se aproximando dos reais. Por conseguinte, as atividades calculadas por este fotopico somente foram comparáveis àquelas obtidas para os demais fotopicos, a partir da quarta série em diante. O fotopico de $344,27 \mathrm{keV}$ sofrendo sobreposiça do fotopico de $345,83 \mathrm{keV}$ do $181 \mathrm{Hf}$ tem sua área líquida subestimada, ao se considerar o procedimento matemático executado pelo programa interno do analisador multicanal.

Eoi efetuada para o 152 Eu uma quinta série de deteçăo, após um periodo de resfriamento de 120 dias, sendo detectados os fotopicos correspondentes às energias de $121,78,344,27,443,96,778,87,964,04,1085,33$ e $1408,02 \mathrm{keV}$. Utilizando-se os dados de todos os fotopicos no cálculo das médias das atividades, observou-se que os 
referentes ao fotopico de $1408,02 \mathrm{keV}$ foram os que mais se aproximaram dos valores médios encontrados para as dez amostras de solos estudadas.

Também para o cobalto, ambos os fotopicos do 60Co foram usados no cálculo final da atividade, näo tendo sido constatadas divergências entre os valores relativos a cada fotopico.

Por consideraçōes já discutidas anteriormente (item 4.4.1), para o háfnio foram empregados somente os valores concernentes ao fotopico de $482,00 \mathrm{keV}$ do $181 \mathrm{Hf}$, pois as atividades calculadas pelo fotopico de $132,94 \mathrm{keV}$ apresentaram-se constantemente inferiores.

4.4.3. Terceira etapa

De posse da estimativa dos fluxos individuais, das taxas liquidas de contagem, do tempo decorrido e demais parâmetros da equação 1, foram calculadas as massas dos elementos para as dez amostras da curva de adicáo. Os teores dos elementos analisados foram correlacionados às quantidades de solo adicionadas para obtença das curvas de regressão linear (Tabela 10 e 11 ). 
Tabela 10. Teores obtidos dos elementos ( $\mu g \cdot g^{-1}$ ) nas amostras da curva de adicáo de s*lo da terceira etapa.

\begin{tabular}{cccccc}
\hline Elemento & Solo $\%$ & Número & Média & Desvio & $\mathrm{CV}$ \\
& MS* & dados & $(\mu \mathrm{g} \cdot \mathrm{g}-1)$ & padräo & $(\%)$ \\
& & & & & \\
\hline \multirow{2}{*}{ Sc } & 0 & 4 & 0,0028 & 0,0004 & 13,9 \\
& 0,5 & 5 & 0,0252 & 0,0020 & 8,0 \\
& 1 & 8 & 0,0463 & 0,0016 & 3,5 \\
1,5 & 5 & 0,0802 & 0,0012 & 1,5 \\
& 2 & 6 & 0,1003 & 0,0016 & 1,6 \\
3 & 6 & 0,1590 & 0,0047 & 3,0 \\
4 & 6 & 0,1876 & 0,0033 & 1,8 \\
6 & 8 & 0,2813 & 0,0063 & 2,2 \\
8 & 6 & 0,3885 & 0,0093 & 2,4 \\
& 100 & 6 & 4,6216 & 0,1114 & 2,4
\end{tabular}

Hf

$\begin{array}{cc}0,5 & 4 \\ 1 & 7 \\ 1,5 & 6 \\ 2 & 6 \\ 3 & 6 \\ 4 & 6 \\ 6 & 6 \\ 8 & 8 \\ 100 & 6\end{array}$

0,0579
0,0606
0,1740
0,2297
0,4782
0,3922
0,7374
0,9697
13,4207

0,0083

0,0085

14,4

0,0129

0,0289

14,1

0,0400

7,4

12,6

0,0243

8,4

0,0918

6,2

0,1100

12,5

11,3

1,4334

10,7

Eu

0,5
1
1,5
2
3
4
6
8
100

1
1
1
2
2
2
2
2
2

0,0013

0,0016

0,0026

0,0088

0,0050

0,0001

0,0020

0,7

0,0068

0,0014

0,0011

0,0018

0,0239

39,2

20,4

7,7

0,0152

0,1643

11,7

20,6 
Tabela 10. Teores obtidos dos elementos $\left(\mu \mathrm{g} \cdot \mathrm{g}^{-1}\right)$ nas amostras da curva de adiça de solo da terceira etapa.

\begin{tabular}{|c|c|c|c|c|c|}
\hline Elemento & $\begin{array}{l}\text { Solo \% } \\
\text { MS* }\end{array}$ & $\begin{array}{l}\text { Número } \\
\text { dados }\end{array}$ & $\begin{array}{l}\text { Média } \\
\left(\mu g \cdot g^{-1}\right)\end{array}$ & $\begin{array}{l}\text { Desvio } \\
\text { padrão }\end{array}$ & $\begin{array}{l}\mathrm{CV} \\
(\%)\end{array}$ \\
\hline La & $\begin{array}{c}0,5 \\
1 \\
1,5 \\
2 \\
3 \\
4 \\
6 \\
8 \\
100\end{array}$ & $\begin{array}{l}4 \\
4 \\
4 \\
4 \\
4 \\
4 \\
4 \\
4 \\
4\end{array}$ & $\begin{array}{l}0,1388 \\
0,1462 \\
0,2921 \\
1,6119 \\
0,3314 \\
0,5403 \\
0,7535 \\
1,1629 \\
13,652\end{array}$ & $\begin{array}{l}0,0186 \\
0,0074 \\
0,0232 \\
0,1125 \\
0,0237 \\
0,0542 \\
0,0527 \\
0,0787 \\
1,006\end{array}$ & $\begin{array}{r}13,4 \\
5,0 \\
7,9 \\
7,0 \\
7,1 \\
10,0 \\
7,0 \\
6,8 \\
7,4\end{array}$ \\
\hline $\mathrm{Sm}$ & $\begin{array}{c}0,5 \\
1 \\
1,5 \\
2 \\
3 \\
4 \\
6 \\
8 \\
100\end{array}$ & $\begin{array}{l}1 \\
1 \\
1 \\
1 \\
1 \\
1 \\
1 \\
1 \\
1\end{array}$ & $\begin{array}{l}0,0275 \\
0,0251 \\
0,0448 \\
0,2544 \\
0,0699 \\
0,0995 \\
0,1483 \\
0,2214 \\
2,6126\end{array}$ & & \\
\hline
\end{tabular}

* Matéria seca da cana com solo 
Tabela 11. Análise da regressá entre $\circ$ solo adicionado à cana e os teores dos elementos analisados nas amostras da terceira etapa.

\begin{tabular}{|c|c|c|c|c|}
\hline Elemento & $\begin{array}{l}\text { Número } \\
\text { dados }\end{array}$ & $\begin{array}{c}\text { Coeficiente } \\
r\end{array}$ & $\begin{array}{c}\text { Teste } \\
t\end{array}$ & $\begin{array}{c}\text { Erro } \\
(5010 \% \text { MS*) }\end{array}$ \\
\hline Escândio & 54 & $0,9980 * *$ & 114,48 & 0,162 \\
\hline Háfnio & 49 & $0,9752 * *$ & 28,22 & 0,588 \\
\hline Európio & 13 & $0,9656 * *$ & 11,14 & 0,722 \\
\hline Lantânio & 32 & $0,9783 * *$ & 24,07 & 0,553 \\
\hline Samário & 8 & $0,9916 * *$ & 17,11 & 0,394 \\
\hline
\end{tabular}

* Matéria seca da cana com solo

** Significativo ao nivel de $0,1 \%$ de probabilidade 
A regressăo para o escandio é resultante de nove pares de dados, sendo cada ponto oriundo da média de seis valores de atividade, relativos aos fotopicos de 889,25 e $1120,51 \mathrm{keV}$ do $46 \mathrm{Sc}$, em três tempos de resfriamento (Eigura 1 ).

- teor médio de escândio encontrado para a amostra sem adiçăo de solo foi equivalente ao desvio padrăo $\left(0,002 \mu g . g^{-1}\right)$ obtido para a amostra com a menor adicáo de solo $(0,5 \%$ de solo na matéria seca). Dessa forma, poderia ser adotado o valor zero para o primeiro par de pontos da regressăo linear entre escândio e solo adicionado, sem causar alteraçóes reais nos resultados.

Este fato já havia sido anteriormente constatado quando, nas análises das dez amostras de cana da segunda etapa, os teores encontrados de escândio foram inferiores a $0,003 \mu \mathrm{g} \cdot \mathrm{g}^{-1}$, independentemente do solo onde foram cultivadas.

A Figura 2 apresenta a curva para o háfnio, elaborada a partir das atividades do $181 \mathrm{Hf}$ obtidas pelos fotopicos de 132,94 e $482,00 \mathrm{keV}$. Nesta etapa, foi possivel utilizar o primeiro fotopico, por se encontrar diferenciado e resolvido. 


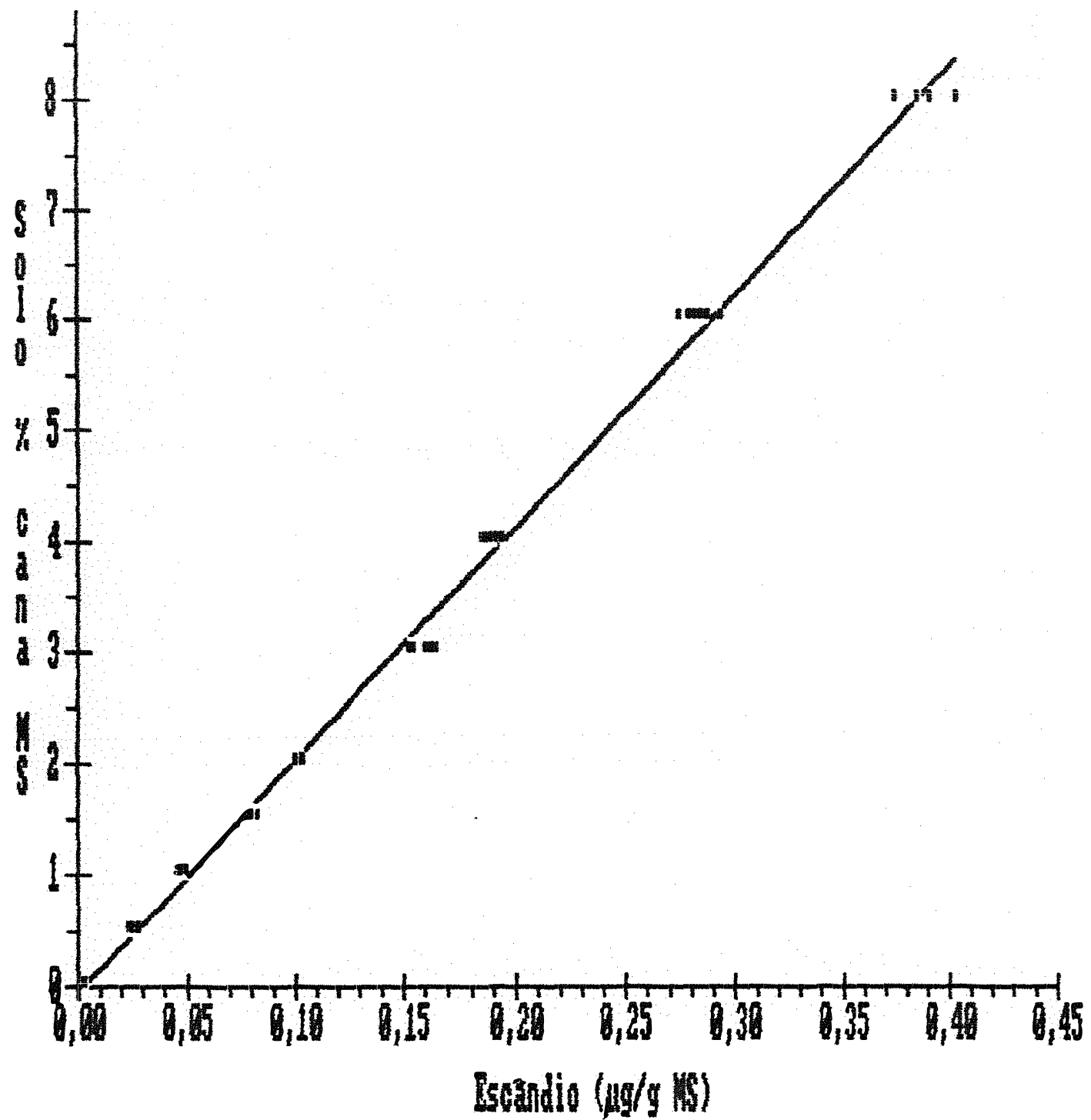

Figura 1. Correlaçăo entre quantidades adicionadas de solo em porcentagem da matéria seca da mistura de cana e solo e os teores encontrados de escandio. 


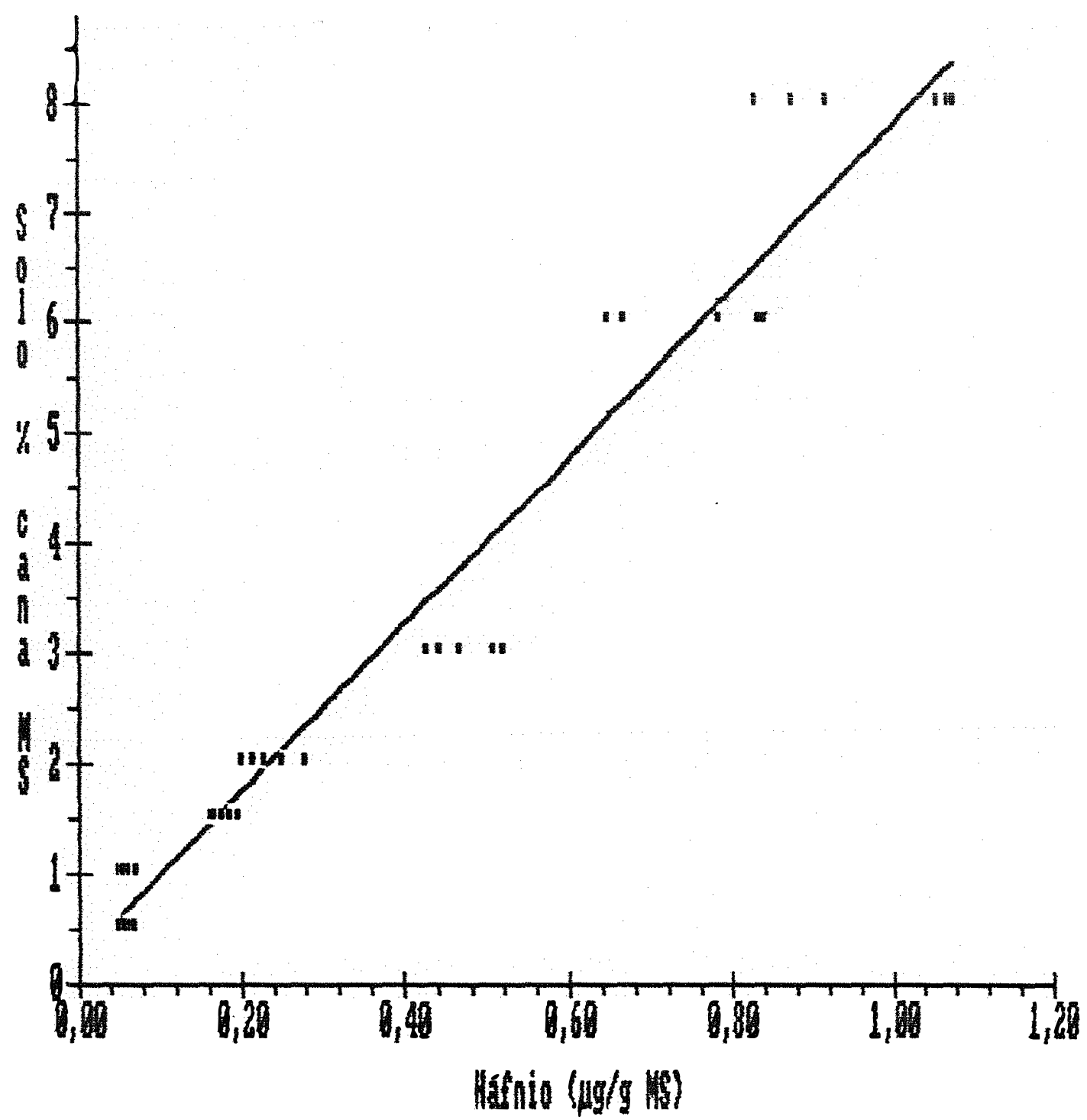

Figura 2. Correlaça entre quantidades adicionadas de solo em porcentagem da matéria seca da mistura de cana e solo e os teores encontrados de háfnio. 
$0153 \mathrm{Sm}$ (Figura 3 ), com meia-vida de $46,7^{\circ} \mathrm{h}$, só foi medido na primeira série para os fotopicos de 69,674 e $103,180 \mathrm{keV}$. Entretanto, o primeiro fotopico năo foi considerado por situar-se em uma faixa desfavorável de baixa eficiência e de emissăo de raios $X$ do material da blindagem. Por ser uma regiăo de alta interferência, estas medidas foram indubitavelmente subestimadas. Este fato foi também notado para o fotopico de $121,78 \mathrm{keV}$ do $152 \mathrm{Eu}$ nas primeiras sêries de detecçäo (Eigura 4).

Para o lantanio, os valores de atividade utilizados na regressáo resultaram da média dos fotopicos de 487,01 e 1596,17 keV, nas duas primeiras séries de detecça (Eigura 5 ).

Como se verifica na Tabela 11, o escandio foi - elemento que apresentou melhor correlaço linear ( $r=$ $0,9980)$, seguido do La $(r=0,9783)$, Hf $(r=0,9752)$ e Eu $(r=0,9656)$ e o menor desvio entre os valores esperados $e$ os realmente obtidos.

Além desses, outro fator que deve ser levado em consideraçăo na escolha do traçador é a quantidade minima diferenciável, ou seja, o erro da estimativa da porcentagem de solo na matéria-prima (Tabela 11). Estes valores foram expressos como razálo de massa de solo por 


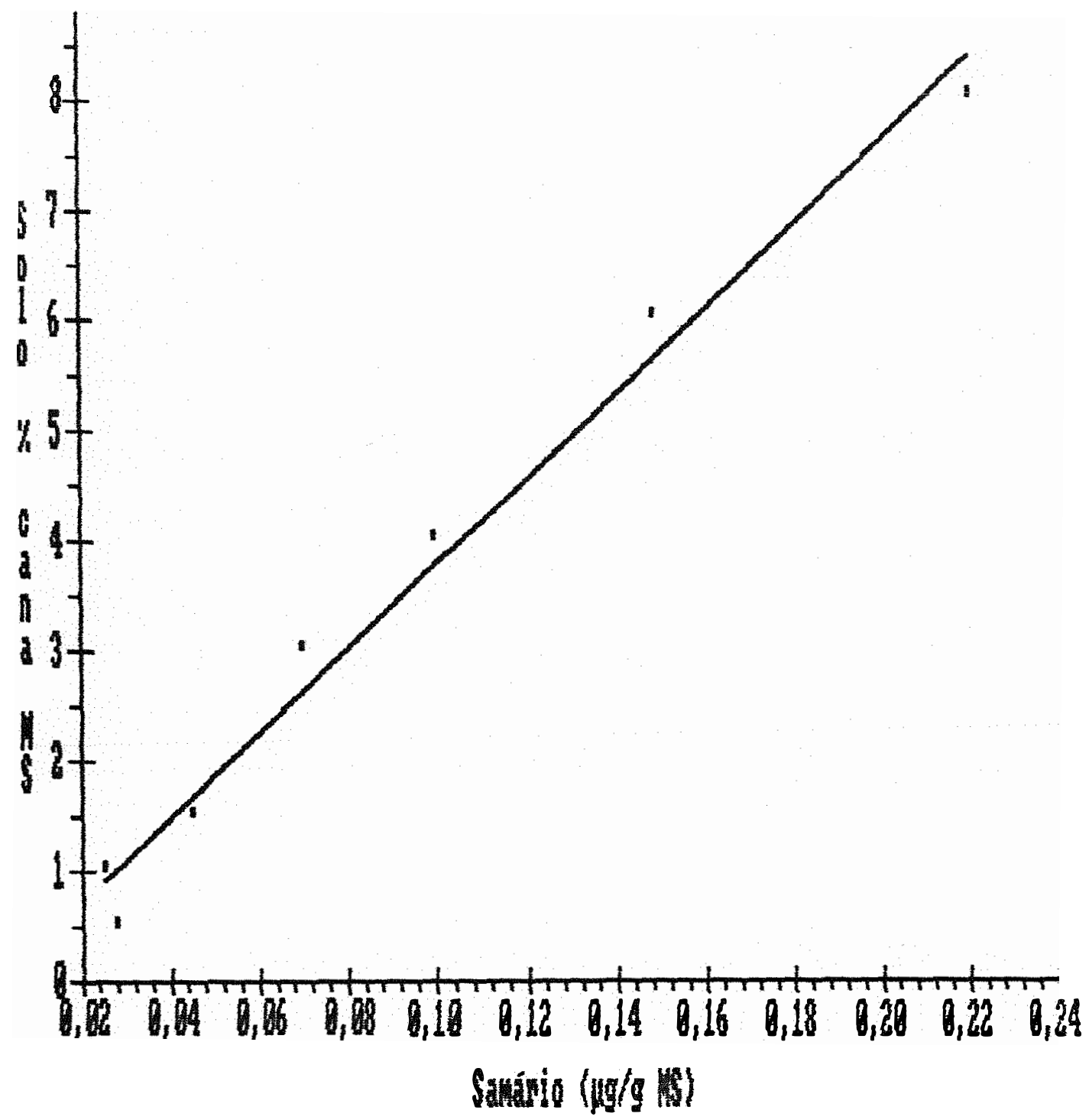

Figura 3. Correlaçäo entre quantidades adicionadas de solo em porcentagem de matéria seca da mistura de cana e solo e os teores encontrados de samário. 


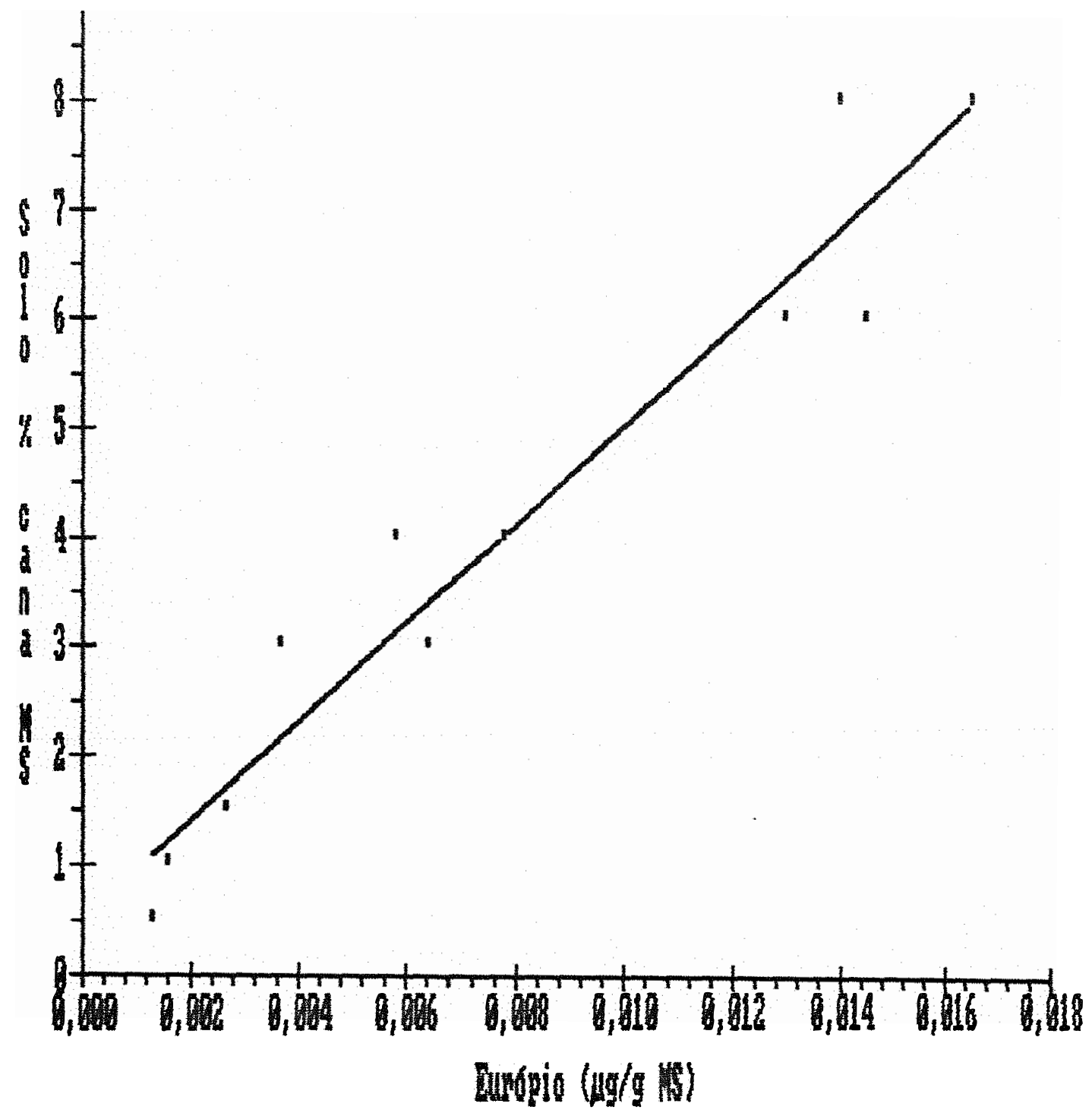

Figura 4. Correlaçăo entre quantidades adicionadas de solo em porcentagem de materia seca da mistura de cana e solo e os teores encontrados de európio. 


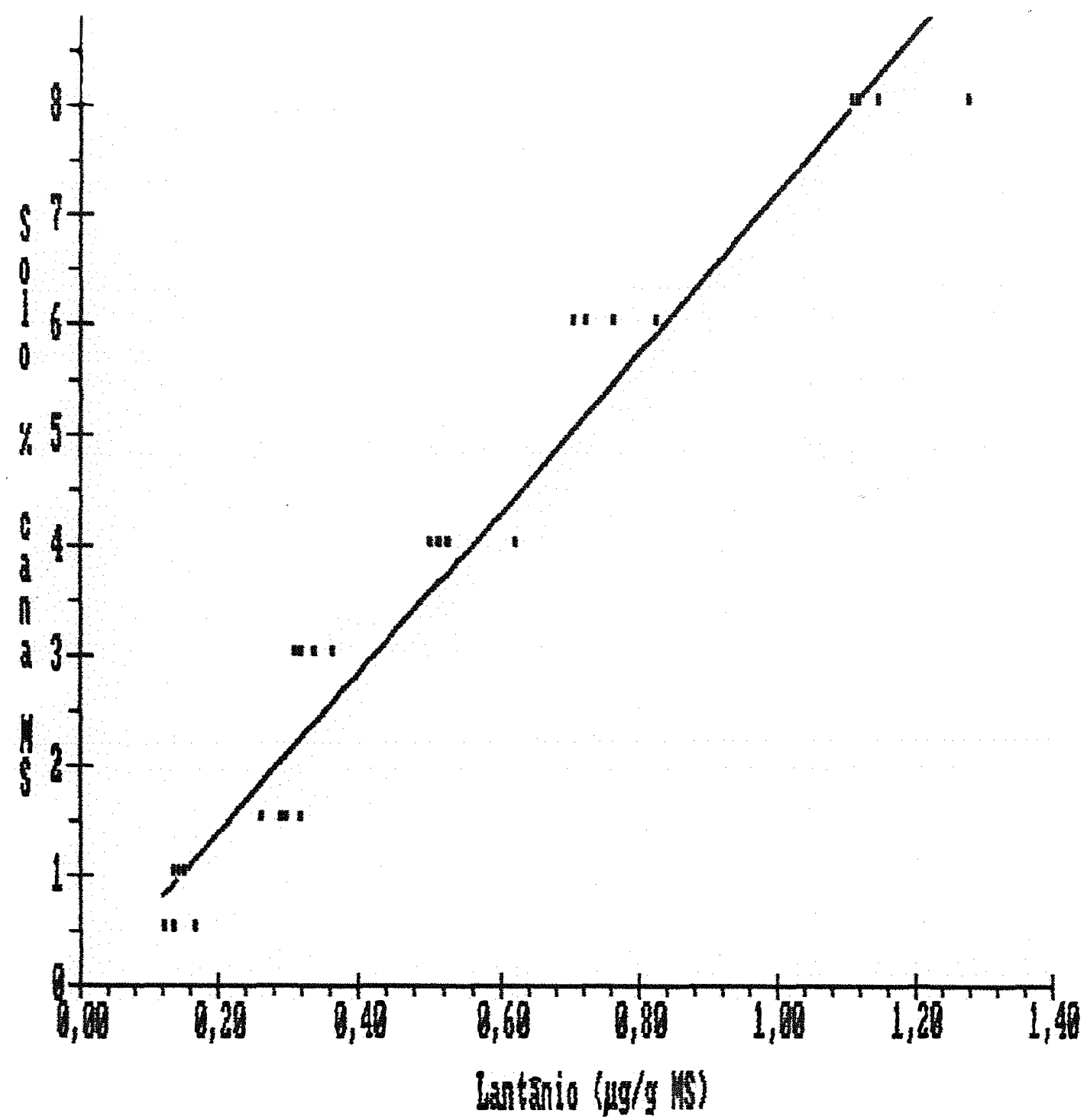

Figura 5. Correlaça entre quantidades adicionadas de solo em porcentagem de matéria seca da mistura de cana e solo e os teores encontrados de lantanio. 
massa de matéria seca (mg.g-1). Considerando-se o teor de umidade da cana $(73,0 \%)$ e transformando-se a massa de solo por cana-de-açúcar "in natura" (kg.t-1), verificou-se que usando o escândio como traçador é possivel diferenciar quantidades de cerca de $0,44 \mathrm{~kg}$ de solo em uma tonelada de matéria-prima. Em segundo lugar, apareceu o samário com $1,06 \mathrm{~kg} \cdot \mathrm{t}^{-1}$, seguido do Iantânio $\left(1,49 \mathrm{~kg} \cdot \mathrm{t}^{-1}\right)$, háfnio $\left(1,59 \mathrm{~kg} \cdot \mathrm{t}^{-1}\right)$ e európio $\left(1,95 \mathrm{~kg} \cdot \mathrm{t}^{-1}\right)$.

4.5. Escândio como traçador

As propriedades biogeoquimicas assim como a abundância na biosfera dos elementos traços e raros do Grupo III săo bastante divergentes. Mais especificamente no Grupo III b, Sc e Y são muito raros no ambiente. Os outros elementos raros săo subdivididos em lantanídeos (também chamados de metais de terras raras) e actinideos, com radionuclideos naturais e artificiais.

A abundância de Sc na litosfera mostra que este elemento é preferencialmente encontrado em rochas máficas (basaltos e gabros; $20-35$ ppm) e em sedimentos argiláceos $(12-15 \mathrm{ppm})$. O Sc ocorre em ambientes naturais predominantemente sob a forma de $5 c^{3+}$, podendo substituir $A^{3+}$, Ee3t, Y3+ e Ti4t. Dessa forma, o elemento 
está principalmente associado a minerais ferromagnesianos e biotita. Em solos de superficie, os teores de Sc variam de 0,5 a $45 \mathrm{ppm}$, sendo governados pelo material de origem. A concentraçăo minima foi encontrada em solos arenosos e fracamente orgânicos, enquanto que quantidades maiores foram relatadas em solos derivados de rochas graniticas e vulcânicas (RABATA-PENDIAS \& PENDIAS, 1985).

Neste trabalho, os teores encontrados de Sc variaram de 4,23 a $65,45 \mathrm{\mu g} \cdot \mathrm{g}^{-1}$ para o latossol vermelhoamarelo de textura barro-arenoso e o latossol roxo de textura argila, respectivamente (Tabela 9). Os teores de ferro $(0,85$ e $18,49 \%$ Fe, Tabela 4$)$ e de carbono $(1,76$ e $4,97 \mathrm{C} \%$ ) relativos a esses solos acompanharam diretamente os de Sc, em concordância com a informaçăo daqueles autores. Os teores de sc foram significativamente correlacionados aos teores de carbono analisados pelo método colorimétrico $(r=0,7245$, ao nivel de $2 \%$ ).

Constatou-se correlaçăo linear significativa ao nivel de $0,1 \%$ de probabilidade $(r=0,9925)$ entre os teores de escândio e de ferro para os dez tipos de solos analisados (Eigura 6). Diversos autores também observaram correlaçáo positiva entre teores de Sc e Ee em solos. KLINE et alii (1969) mostraram fortes indicaços da relaçăo Sc/Ee em solos glaciais de Wisconsin ( $r=0,99 *$ ). 


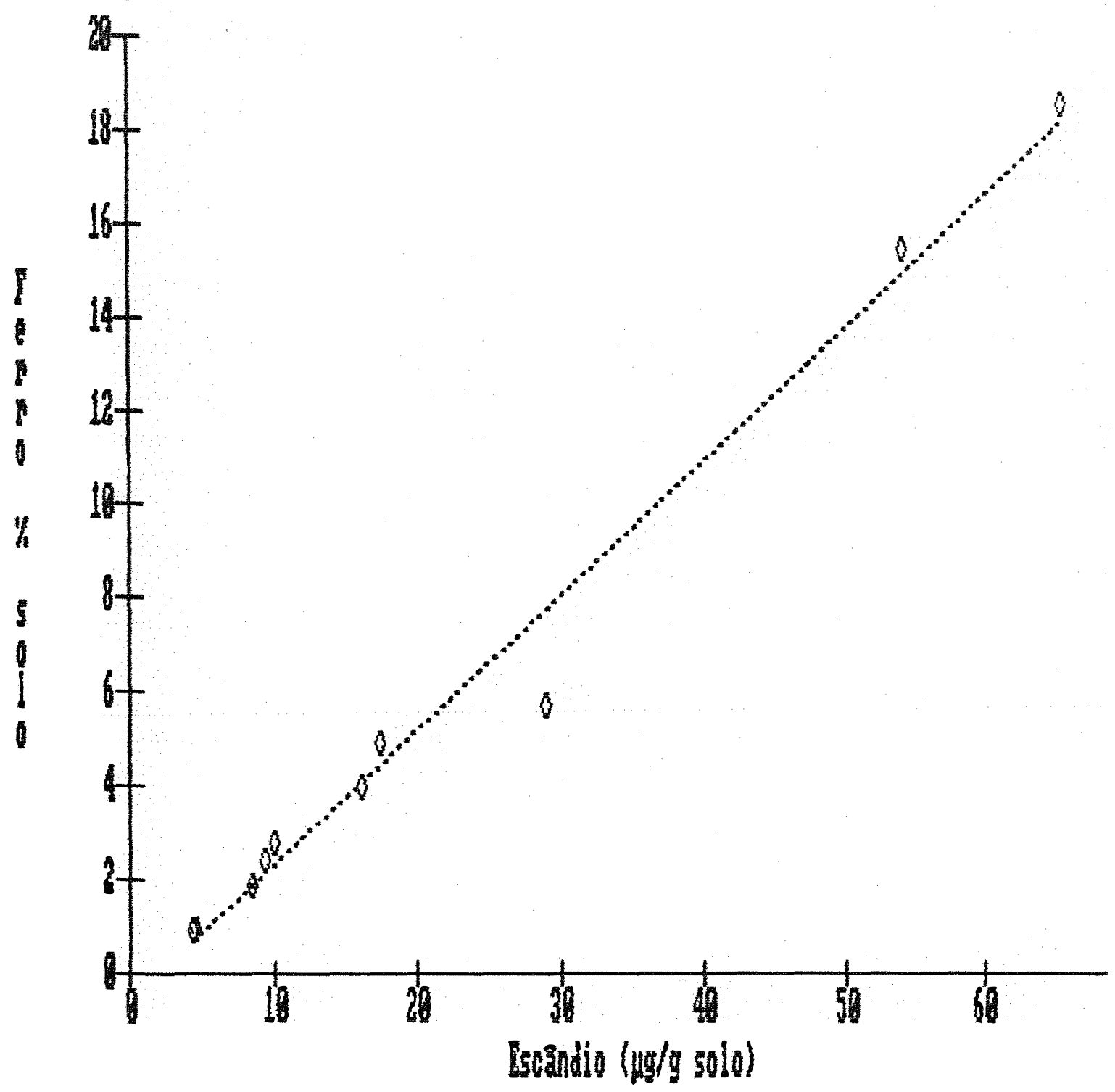

Figura 6. Correlaçäo entre os teores de escandio e de ferro encontrados nos dez solos analisados. 
Parece que a associaçáo existente é determinada pelas relaçöes geoquímicas do material de origem, preservadas durante o subseqüente processo de intemperismo.

Os espectros de raios gama de uma coleçăo de solos englobando diversas regiöes do mundo (Libano, Malàia, Nova Zelândia, Noruega, Japão, Brasil, Austrália, Estados Unidos, Rodésia e Havaí), obtidos após ativaçăo com nêutrons térmicos, foram analisados para identificar e medir elementos traços e verificar a possibilidade de relacionar os solos com a origem geográfica (KLINE \& BRAR, 1969). A aparente similaridade entre os espectros é resultado da razăo constante observada entre Sc e Ee, a despeito das origens bastante diversificadas dos solos amostrados. Foi encontrada correlaça logaritmica $\left(r^{2}=\right.$ 0,80 ) entre as quantidades desses elementos nas treze amostras de solos. Este fato sugere ser o comportamento geoquímico de SC e Fe bastante similar, independentemente das condiçóes de intemperismo a que os solos foram submetidos.

Para os dez solos amostrados na regiăo Canavieira do Estado de Säo Palulo, a razáo sc/Ee do horizonte superficial situou-se entre 3,6 a 4,9.10-4, com valor médio de $4,2 \cdot 10^{-4}(\mathrm{CV}=15 \%)$, resultado semelhante àquele obtido em oregon, em condicoses totalmente diversas, 
para solos originados de cinzas vulcânicas (BORCHARDT \& HARWARD, 1971). Os autores encontraram perfeita correlaçăo dos elementos traços dos horizontes $\mathrm{C}$ com o material de origem (erupçäo do Monte Mazama), salientando que nas cinco localizaçóes de coletas de amostra, ao longo de 450 $\mathrm{km}$ de caminhamento, a razáo $\mathrm{Sc} / \mathrm{Ee}$ permaneceu constante, com valor médio de $4,1 \cdot 10^{-4}(\mathrm{CV}=8 \%)$. Ressaltaram ainda que a razáo $\mathrm{Sc} / \mathrm{Fe}$ bem como as abundancias de Hf, The elementos de terras raras permaneceram relativamente constantes com a profundidade nos perfis dos solos amostrados. Se esta condiçăo for também válida para os solos em estudo, entåo, a preocupaçäo quanto à representatividade da camada amostrada de 5010 (5 cm de profundidade) relativamente àquele aderido aos colmos deixa de ser relevante.

As quantidades de escândio das amostras de solos foram calculadas assumindo-se que todo $046 \mathrm{Sc}$ tenha sido originado unicamente pela reaçăo $45 \mathrm{Sc}(n, \gamma) 46 \mathrm{Sc}$. Esta hipótese foi baseada no fato de que a reaçăo interferente $46 \mathrm{Ti}(n, p) 46 \mathrm{Sc}$ tem baixa probabilidade de ocorrência, uma vez que as amostras foram submetidas a fluxo de nêtrons bem termalizados, com contribuiçăo epitemmica desprezivel na posiçăo de irradiaçăo, distante do caroço do reator. Neste aspecto, avaliando a composicăo elementar de nove unidades de solo do litoral de Pernambuco, DANTAS \& 
RUE (1975) observaram que as interferências provocadas por certas reaçöes induzidas em macroelementos componentes das amostras de solo, como $51 \mathrm{Fe}(\mathrm{n}, \mathrm{p}) 51 \mathrm{Cr}, 56 \mathrm{Fe}(\mathrm{n}, \mathrm{p}) 56 \mathrm{Mn}$ e $46 \mathrm{Ti}(n, p) 45 \mathrm{Sc}$, mostraram-se negligenciáveis em ativaçäo com nêutrons térmicos, mesmo quando as amostras eram irradiadas em posiçóes especificas do reator com fluxo relativamente alto de nêtrons rápidos.

Deve-se ter em consideraçäo que o Ti está presente em solos ao nivel de porcentagem, ao passo que 0 Sc, normalmente em ppm, além do que o 46Ti apresenta seção de choque favorável para nêutrons rápidos (MURRMANN et alii, 1971). Assim sendo, solos derivados de rochas eruptivas básicas como, por exemplo, as amostras de terra roxa estruturada (solo 9) e latossol roxo (solo 6) podem apresentar altos teores de óxido de ferro e de titânio, características herdadas do material de origem. Realmente, valores significativamente altos de $\mathrm{Fe}_{2} \mathrm{O}_{3}$ foram constatados para estes solos, correspondendo a 22,02 e $26,43 \%$, respectivamente. Entretanto, a avaliaçăo dos teores de titânio em solos por ativaçäo com nêtrons têrmicos tem como comprometimento a meia-vida de 5,76 min do nuclideo produzido pela reaça $50 \mathrm{Ti}(\mathrm{n}, y) 51 \mathrm{Ti}$, o que impossibitou sua deteçăo nas condicóes experimentais adotadas neste trabalho. 
- Muitos dos nuclideos dos elementos componentes dos solos que se tornaram radioativos devido à captura de nêutrons térmicos, resultando em radionuclídeos de meiasvidas apreciáveis, såo membros ou da primeira série de metais de transiçăo ou da série de terras raras. Estes elementos têm comportamento geoquimico parecido e suas quantidades nos solos deste estudo foram correlacionadas entre si.

Para os dez diferentes solos estudados, foi testada regressăo linear entre escândio e cobalto, elemento da primeira série dos metais de transicăo, obtendo-se $\circ$ coeficiente de correlaçăo ( $r=0,8542)$, significativo ao nível de $1 \%$ de probabilidade. A correlaçáo entre estes elementos já havia sido relatada por KLINE \& BRAR (1969), com $r^{2}$ igual a 0,96 .

Algumas vezes $\circ$ Sc é incluido nas discussőes relativas aos elementos de terras raras, por ocorrer no mesmo grupo periódico. Embora HASKIN \& EREY (1966) terem sugerido que seu comportamento é consideravelmente diferente, correlaçöes entre So e Eu foram altamente significativas, com $r^{2}$ igual a 0,89 (KLINE \& BRAR, 1969). Neste estudo, foi observada correlaça significativa ao nivel de $0,1 \%$ de probabilidade entre esses dois elementos $(r=0,9137)$. Correlaçăo significativa $(r=0,7658)$ ao 
nivel de $1 \%$ de probabilidade foi também verificada entre os teores de $\mathrm{Sc}$ e de La nos solos amostrados.

A fraçăo argila do solo é a que apresenta maior aderência aos colmos de cana-de-açúcar durante a colheita, quando em contacto com $\circ$ solo, por suas caracteristicas peculiares de grande área de superficie e reduzida granulometria. Entretanto, conforme salientado por BRAUNBECK \& BANCHI (1988), quando a cana-de-açúcar é arrastada pela garra ou rastelo da carregadora mecânica sobre solos arenosos e, portanto, menos compactados na superficie, maior quantidade de terra $e$ carregada com a matéria-prima. Este aspecto sugere pesquisas complementares entre o elemento traçador da porcentagem de impurezas, o escândio, e as fraçóes dos componentes do solo.

Para os diferentes tipos de solos analisados, năo foi observada regressáo linear única entre os teores de escândio e toda a faíxa de variaçăo dos teores de argila. Efetivamente, parece existir um padrão de comportamento até certos limites, em torno de $20 \%$ de argila (Eigura 7). KLINE et alii (1969) obtiveram correlaços significativas entre teores de sc e de argilas em perfis de solos $(r=0,8892 * *)$. O Sc está associado às argilas pelo comportamento de intemperismo, podendo ser 


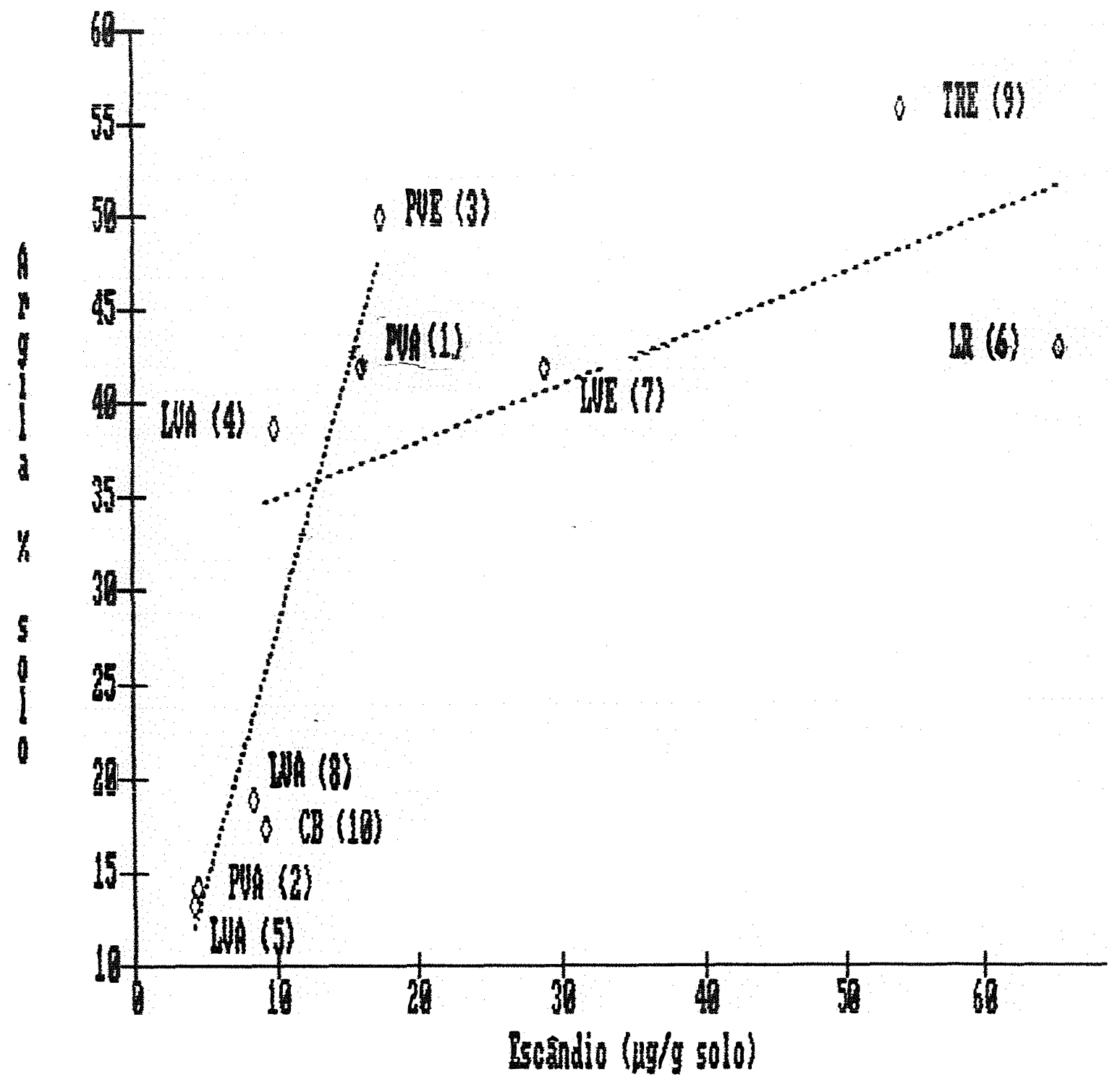

Figura 7. Correlaça entre os teores de escandio e os valores da fracáo argila encontrados nos dez solos estudados. 
parcialmente influenciado pelos mesmos processos que atuam na formaçăo do mineral de argila e sua translocacăo.

A habilidade das diferentes plantas em absorver elementos tracos varia grandemente. Entretanto, fazendo-se uma comparaçăo em grande escala, o indice de acumulaçăo - calculado como a razăo dos elementos tracos em plantas pelas suas concentraçoes nos solos, baseados em dados de diferentes solos e plantas - ilustra alguns comportamentos generalizados. Alguns elementos como $\mathrm{Cd}, \mathrm{B}$, $\mathrm{Br}, \mathrm{Cs}$ e Rb săo de absoróa extremamente facil, enquanto que $\mathrm{Ba}, \mathrm{Ti}, \mathrm{Zr}, \mathrm{Sc}, \mathrm{Bi}, \mathrm{Ga}$ e, em certa extensăo, $\mathrm{Fe}$ e $\mathrm{Se}$, săo fracamente disponiveis às plantas (KABATA-PENDIAS \& PENDIAS, 1985).

Para as dez amostras de cana-de-aciacar analisadas da variedade SP 71-1406, näo foi observado aumento sistemático na quantidade absorvida pelas plantas com $\circ$ aumento das quantidades totais dos elementos encontradas nos solos. Neste aspecto, NADKARNI (1976) já havia evidenciado que $\circ$ comportamento de extraçăo dos metais dos solos é complexo e depende de uma série de fatores como fases uinerais, condiçes da soluço do solo, pH, populaçăo microbiana, constituintes orgânicos, etc. 
Existem poucos dados na literatura a respeito da distribuicăo de $3 c$ em plantas e, especialmente, em cana-de-acúcar. MOHAMED (1986), através da análise por ativaço neutrónica instrumental multielementar determinou diversos elementos macro, tracos e ultratracos em bagaco de cana-de-acúcar de cinco usinas (Aswan, Egito). Pela utilizaço de $2 \mathrm{~g}$ de amostra, foi possivel detectar a presenca de Sc em bagacos, cujos teores situaram-se na faixa de 1,109 a $5,170 \mathrm{ppb}$ ( $\approx 2 \mathrm{ppb}$ ), em concordância aos dados encontrados neste trabalho $(\approx 3 \mathrm{ppb})$. As variacóes nos resultados foram relacionadas a diferentes estruturas botânicas, composicŏes diversas da cana-de-açucar ou a alteracöes ecologicas no solo. Além disso, os autores afirmaram que a presenca de elementos tracos nos bagacos é, em grande parte, dependente dos elementos tracos disponiveis no solo, fertilizantes e na água de irrigaçá.

Estudos relativos ao ciclo de elementos em ambientes naturais têm sido realizados, como a entrada de elementos oriundos da atmosfera em solos e lencóis freáticos e a influência da suspensáo de poeira do solo na composiçáo quali-quantitativa da atmosfera. Para se avaliar o impacto da poluicáo ambiental em locais de prospeccáo de metais, a análise multielementar de particulados do ar, solo e vegetaçáo foi efetuada, tomando-se o escândio como elemento normalizador, por se 
considerar que a única fonte desso elemento $\dot{0} 0$ solo (SALMON \& CAWSE, 1986).

Estes autores estabeleceram as razoes de 23 elementos com Sc (ao invés dos elementos normalmente utilizados, como Al ou Fe), para comparar os padröea multielementares da deposiçăo atmosférica total com o dé graineas e os de solos de superficie. A escolha do So foi devida ao fato de que as plantas mostram desprezivel retirada e translocasáo de Sc. Em consequencia, qualquer incremento nas razbes relativas dos elementos, tanto do solo como da deposiçăo total, demonstrará a absorcáo ocorrida através das raizes ou folhas.

Em estudos de composiçăo, enriquecimento e fontes de aerosóis, 20 elementos foram analisados por ativaçăo neutrônica instrumental em solos de superficie, subsolo e profundos por GORDON (1975). O enriquecimento de particulados do ar relativamente aos solos foi avaliado por normalizagáo dupla a um elemento, geralmente nžo utilizado na indústria, porem amplamente encontrado em solos. Entäo, com este procedimento, um fator de enriquecimento $\hat{\varepsilon}$ obtido, normalmente baseado em lum dos elementos normalizantes Al, Ce, Ee, Sc ou Ti. 
i Iiteratura demonstra que, no sistema soloplanta-atmosfera, o escândio está universalmente distribuido em solos e ná é significativamente absorvido pelas plantas. A análise das dez amostras de solo de formaçóes geológicas distintas mostrou que o escândio está sempre presente, tendo-se observado teores entre 4 e 66 Mg.g-1. Paralelamente, as dez amostras de cana, procedentes desses mesmos solos, apresentaram teores inferiores a $0,003 \mathrm{\mu g} \cdot \mathrm{g}^{-1}$, independentemente da quantidade de escândio existente no solo. Portanto, no sistema solocana é perfeitamente viável o uso do escândio como tracador de solo, pela ativaço do nuclideo estável $455 \mathrm{c}$ e subseqüente análise do $46 \mathrm{Sc}$ formado. 
5. CONCLUSOES

Pode-se quantificar o teor de solo incorporado à cana-de-açucar durante a colheita, através de ativaçáo neutrônica das amostras com deteç̧áo da radioatividade induzida por espectrometria gama de alta resoluça.

Dentre os elementos investigados, o escândio mostrou-se o mais adequado para ser usado como tracador. O nuclídeo $45 \mathrm{Sc}$ apresenta características físicas favoráveis para ativaçăo com nêtrons térmicos como seçác de choque e abundância isotópica, enquanto que $\circ$ radionuclideo $465 \mathrm{C}$ formado, dois fotopicos bem localizados no espectro, alem da meia-vida adequada às condiçöes experimentais adotadas.

Usando-se o escândio constituinte do solo como tracador, é possível diferenciar quantidades da ordem de $500 \mathrm{~g}$ de solo por tonelada de cana entregue às lasinas ou 
destilarias como materia-prima. Este valor se refere à condicáo mais desfavoravel, ou seja, para um solo bastante arenoso com o menor teor de escandio encontrado. Para solos com teores mais elevados desse elemento, o limite deve ser menor.

Devido à reprodutibilidade dos dados obtidos para o escandio, nas sêries de deteccaro efetuadas em diversos tempos de resfriamento, concluiu-se que apenas uma determinaçăo (em torno de 10 dias após a irradiaçăo) é suficiente, näo acarretando perda de precisăo e reduzindo consideravelmente o tempo total da análise.

- método da padronizaçáo interna usando o próprio ferro constituinte do solo como referência foi viável para estimativa do fluxo de nêtrons, uma vez que a determinaçáo desse elemento por via química é de alta precisão e exatidão. 
REEERENCIAS BIBLIOGRAEICAS

ADAMS, E. \& DAMS, R. Applied Gamma-Ray Spectrometry, 2nd ed. Great Britain, Pergamon Press, 753p, 1975.

ATTALA, L.T. Anklise por ativacáo de aerosbis: comparacáo dos resultados por dois programas de computaça. Sao Paulo, Institutio Energia Atômica, IEA-435, 36p, 1976.

ATTALA, L.T. \& REQUEJO, C.S. Análise por ativaçåo multielementar de carvöes brasileiros. Sáo Paulo, Instituto Pesquisas Energeticas e Nucleares, Pub-48, $20 \mathrm{p}, 1982$.

AYLMER, J.A. \& HOLMES, R.L. Soil determination in bulk shredded sugar cane. Int. Sug. J. 83(996):362-364, 1981 . 
BARBIERI, J.L. \& POLI, D.M. Fertilidade dos principais solos cultivados com cana-de-açúcar. Reuniáo Técnica Agronômica "Manejo da adubaçäo na cultura da cana-deaçúcar". Centro Tecnologia Copersucar,11-18, 1984.

BORCHARDT, G.A. \& HARWARD, M.E. Trace element correlation of volcanic ash soils. Soil Sci. Soc. Amer. Proc., $35: 626-631,1971$.

BRAUNBECK, O.A. \& BANCHI, A.D. Carregamento mecânicoreducao de impurezas minerais. Bol. Tecn. Copersucar $43: 35-42,1988$.

BROKENSHA, M.A. \& MELLET, P. Sampling and analysis of prepared cane for its ash content with reference to estimating soil levels in cane. Proc. South African Sug. Technol. Assoc., 51:97-100, 1977.

BURGER, W.R. \& NIX, K.J. Harvesting and cane quality. Proc. Australian Soc. Sug. Cane Technol., p.33-39, 1979 .

BRUNE, D.; EORKMAN, B. \& PERSSON, B. Nuclear Analytical Chemistry. Chartwell-Bratt Ltd., Sweden. 557p., 1984. 
DANTAS, C.C. \& RUF, H. Determination of minor constituent elements in soils by instrumental neutron activation analysis. Radiochimica Acta, 22:192-198, 1975.

De CORTE, F.; SPEECKE, A. \& HOSTE, J. Reactor neutron activation analysis by a triple comparator method. J. Radioanal. Chem. 3:205-215, 1969.

De CORTE, F.; Simonits, A.; De Wispelaere, A. \& HOSTE, J. Accuracy and applicability of the ko - Standardization method. J. Radioanal. Nucl. Chem., Articles, $113(I): 145-161,1987$.

De SOETE, D.; GIJBELS, R, \& HOSTE, J. Neutron Activation Analysis. London, Wiley \& Sons. 836p. 1972.

EKSTROM, L.P. \& ANDERSSON, P. Catalogue of gamma rays from radionuclides. Depart. Physics, University of Lund, Sweden, 2nd ed., 192p. 1985.

EKSTROM, L.P:; ANDERSSON,P. \& SHEPPARD, H.M. Catalogue of gamma rays radionuclides ordered by nuclide. Depart. Physics, University of Lund, Sweden, 2nd ed, 250p. 1985 . 
FERNANDES, A.C. \& OLIVEIRA, E.R. Sugarcane trash measurements in Brazil. Proc. XVI Cong. Int. Soc. Sug. Cane Tech., Săo Paulo, Brasil, 2:1963-1973, 1977.

EERNANDES, A.C. \& IRVINE, J.E. The brazilian sugar and alcohol agroindustry. Copersucar Int. Sugarcane Breeding Workshop, Copersucar, Piracicaba/SP, p.233$248,1987$.

GINE, M.F.G. Análises de rochas por espectrometria de emissăo atômica com plasma induzido empregando sistema de injecăo em fluxo e metodo generalizado das adicöes padrăo. Tese de Doutorado, ESALQ/USP, 93p, Piracicala, 1986.

GIRARDI, E.; GUZZI, G. \& PAULY, J. Activation analysis by absolute gamma-ray counting and direct calculation of weights from nuclear constants. Anal. Chem., $36(8): 1588-1594,1964$.

GIRARDI, F .; GUZZI, G. \& PAULY, J. Reactor neutron activation analysis by the single comparator method. Anal. Chem., 37(9):1085-1092, 1965.

GONCALVES, L.A.C. Influência da fibra e da pol da cana e da pureza do caido no processo de fabricacia de achicar 
e álcool. Brasil Açucareiro, Río de Janeiro, 105(4,5 e 6) : 49-64, 1987 .

GORDON, G.E. Atmosferic Impact of Major Sources and Consumers of Energy. Progress Report, Univ. Maryland Dept. Chemistry, Maryland, 1975.

GREENBERG, R.R. The role of neutron activation analysis in the certification of NBS standard reference materials. J. Radioanal. Nucl. Chem. 113(1):233-247, 1987.

HASKIN, L.A. \& EREY, E.A. Dispersed and not-so-rare earths. Science, 152(3720):299-314. 1966.

HEATH, R.L. Table of the Isotopes (1985 update). IN: CRCHandbook of Chemistry and Physics. $66^{t h}$ ed. Boca Raton, Florida, CRC Press, p.B233-B454, 1985.

HEYDORN, $K$. Recent developments in nuclear activation analysis. Isotopenpraxis, 24(2):45-48, 1988.

HOSTE, J; BOUTEN, P. \& ADAM, E. Minor-constituent analysis with neutron activation. Nucleonics $19(3): 118-123$, 1961. 
IAEA- Information sheet. Certified Reference Material, Soil-5. International Atomic Energy Agency, Vienna, Austria, 7p., 1978.

KABATA-PENDIAS, A. \& PENDIAS, H. Trace Elements in Soils and Plants. $3 \mathrm{rd}$ ed. Boca Raton, Elorida, CRC Press. 315 p., 1985 .

KLINE, J.R. \& BRAR, S.S. Instrumental analysis of neutron irradiated soils. Soil Sci. Soc. Amer. Proc., 33:234238,1969 .

KLINE, J.R.; EOSS, J.E. \& BRAR, S.S. Lanthanum and scandium distribution in three glacial soils of Western Wisconsin. Soil Sci. Soc. Amer. Proc., 33:287-291, 1969 .

KOONS, R.D. \& HELMKE, P.A. Neutron activation analysis of standard soils. Soil Sci. Soc. Amer. J., 42:237-240, 1978 .

KRUG, E.J.; BERGAMIN EO, H.; ZAGATTO, E.A.G. \& JØRGENSEN, S.S. Rapid determination of sulphate in natural waters and plant digests by continuous flow injection turbidimetry. Analyst, 102:503-508, 1977. 
LAMUSSE, J.P. \& MUNSAMY, S. Extraneous matter in cane and its effect on the extraction plant. Proc. South African Sug. Technol. Assoc., 84-89, 1979.

LELIAERT, G.; HOSTE, J. \& EECKHAUT, J. Activation analysis of vanadium in high alloy steels using manganese as internal standard. Anal. Chim. Acta, 19:100-107, 1958.

LOUGHRAN, J.; COWAN, G. \& MASON, V. Application of a neutron activation method for routine determination of dirt content in prepared cane. Proc. XVIII Int. Sug. Soc. Cane Technol., 3:11-31, 1983.

MACHADO Jr, G.R. Censo varietal 1985 das usinas cooperadas Copersucar e usinas da regiăo centro-sul do Brasil. Bol. Tecn. Copersucar, 35:54-57, 1986.

MOHAMED, A.E. Determination of trace elements in sugar cane refuse by instrumental neutron activation analysis. J. Radioanal. Nucl. Chem., Letters 107(2):121128,1986 .

MULLER, R.L.; PLAYER, M.R. \& NISE, M.B. An examination of input, disposition and effect on dirt in Queesland sugar mills. Proc. Australian Soc. Cane Technol., Townsville, Queensland, $1-9,1982$. 
MURRMANN, R.P.; WINTERS,R.W. \& MARTIN, T.G. Determination of trace elements in soils and clay minerals by resonance neutron activation analysis. Soil Sci. Soc. Amer. Proc., 35:647-652, 1971.

NADRARNI, R.A. Elemental availability to plants from soils solutions studied by neutron activation analysis. Radiochem. Radioanal. Letters, 26(2):139-150, 1976.

NADKARNI, R.A. \& MORRISON, G.H. Use of standard reference materials as multielement irradiation standards in neutron activation analysis. J. Radioanal. Chem., $43: 347-352,1978$.

NASCIMENTO FO, V.F.; FERNANDES, E.A.N.; FERRAZ, E.S.B. \& PESSENDA, L.C.R. Uso da análise por ativaçăo neutrônica com fonte radioativa de $252 \mathrm{Cf}$ na determinaçăo do teor de solo em cana preparada. Anais do I Congresso Geral de Energia Nuclear, Rio de Janeiro, 4p. 1986.

NASCIMENTO FO, V.F.; MARQUES, D.A.; FERNANDES, E.A.N.; PESSENDA, L.C.R. \& FERRAZ, E.S.B. Programa em Basic para microcomputador da linha Apple para interpretaçäo de espectros de pulsos de raios gama em sistema detector de alta resoluçäo. Anais do II Congresso Geral de Energia Nuclear, Rio de Janeiro, 10p. 1988. 
NASCIMENTO FO, V.F.; MENDES FO, M.; FERRAZ, E.S.B.; FERNANDES, E.A.N. \& PESSENDA, L.C.R. Possibilidade de emprego de análise por fluorescência de raios $X$ na determinaçáo do teor de solo em cana preparada. Anais do I Congresso Geral de Energia Nuclear, Rio de Janeiro, 5p. 1986.

NEETHLING, M.V. Different loading systems and their effect on soil in cane. Proc. South African Sug. Tech. Assoc. $4-6,1982$.

ROUCHAUD, J.C.; DEBOVE, L.; EEDOROEE, M.; MOSULISHVILI, L.M.; DUNDUA, V.Yu; KHARABADZE, N.E; SHONIA, N.I.; EEREMOVA, E. Yu. \& CHIKHLADZE, N.V. A comparison of synthetic irradiation-resistant multielement standards for activation analysis. J. Radioanal. Nucl. Chem., Articles, 113(I): 209-215, 1987 .

SALMON, L. \& CAWSE, P.A. Instrumental Neutron Activation Analysis. IN: SMITH, K.A., Soil Analysis Instrumental Techniques and Related Procedures. New York, Marcel Dekker, Inc., cap.7, 299-346, 1986.

SIMONITS, A.; De CORTE, F.\& HOSTE, J. Single-comparator methods in reactor neutron activation analysis. $J$. Radioanal. Chem. 24:31-46, 1975 . 
SIMONITS, A.; De CORTE, F.; DE NISPELAERE, A. \& HOSTE, J. Nuclear data measurements for zirconium isotopes used for activation analysis and neutron metrology. J. Radioanal. Nucl. Chem. 113(1):187-197, 1987.

ZAGATTO, E.A.G.; JACINTHO, A.O.; REIS, B.E.; BERGAMIN EO, H.; PESSENDA, L.C.R.; MORTATTI, J. \& GINE, M.E. Manual de análises de plantas e águas empregando sistemas de injeça om fluxo. Piracicaba/SP, CENA/USP, 45p. 1981. 